\title{
Organic Dyes Adsorption on the Almond Shell (Prunus dulcis) as Agricultural Solid Waste from Aqueous Solution in Single and Binary Mixture Systems
}

\author{
Mohammed El Khomri 1,", Noureddine El Messaoudi 1,", Abdellah Dbik ${ }^{1}$, Safae Bentahar ${ }^{1}$, Abdellah \\ Lacherai ${ }^{1}$, Zahra Goodarzvand Chegini ${ }^{2}$, Munawar Iqbal ${ }^{3}$

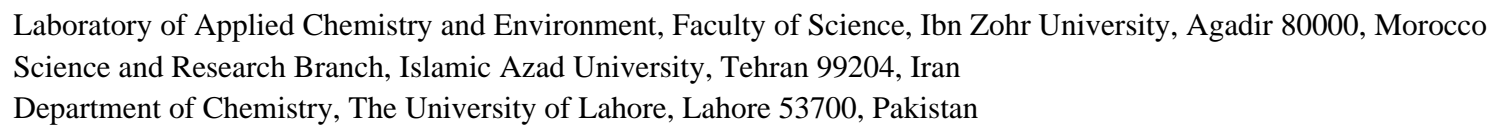

Scopus Author ID 56465946700

Received: 3.05.2021; Revised: 1.06.2021; Accepted: 4.06.2021; Published: 18.06.2021

\begin{abstract}
Almond shell (AS) is a low-cost adsorbent used in this study for the removal of methylene blue (MB), crystal violet (CV), and Congo red (CR) from an aqueous solution in single and mixture binary systems. The low-cost adsorbent was characterized by FTIR and SEM analysis. The effects of AS dose, contact time, initial dye concentration, $\mathrm{pH}$, and temperature on $\mathrm{MB}, \mathrm{CV}$, and $\mathrm{CR}$ adsorption were studied in a single system. In a binary system, the MB, CV, and CR were removed from the mixture of $\mathrm{MB}+\mathrm{CR}, \mathrm{CV}+\mathrm{MB}$, and $\mathrm{CV}+\mathrm{CR}$ with a percentage in volume ranging from 0 to $100 \%$ in $\mathrm{MB}$ and $\mathrm{CV}$, and $\mathrm{CR}$. Kinetic studies showed rapid sorption following a second-order kinetic model with of contact time of $10 \mathrm{~min}$. The modulation of adsorption isotherms showed that retention follows the Langmuir model. The thermodynamic parameters proved that the $\mathrm{MB}, \mathrm{CV}$, and $\mathrm{CR}$ adsorption process was feasible, spontaneous, and exothermic. The synergy adsorption between dyes in a binary mixture of $\mathrm{MB}+\mathrm{CR}$ and $\mathrm{CV}+\mathrm{CR}$, while the competition adsorption between dyes in a binary mixture of $\mathrm{MB}+\mathrm{CV}$.
\end{abstract}

Keywords: dye organic; adsorption; almond shell; single system; binary system.

(C) 2021 by the authors. This article is an open-access article distributed under the terms and conditions of the Creative Commons Attribution (CC BY) license (https://creativecommons.org/licenses/by/4.0/).

\section{Introduction}

Many industries such as textile, food, paper, and pharmaceutical industries used dyes to color their product $[1,2]$. Despite the diversity of fields of application, its presence, even in small quantities, unbalances aquatic environments by inhibiting access to the sunlight absorbed by phytoplankton and hydrophytes [3]. Also, inhalation can give rise to breathing difficulties and palpitations. Dye is also mutagenic and carcinogenic for humans and other living beings [4,5]. So, its elimination from wastewater is a fundamental challenge for a scientist [6].

Numerous studies have used many methods for dye removals such as degradation, coagulation, photocatalysis, flocculation, hydrogen peroxide, adsorption, oxidation, irradiation, ion exchange, reverse osmosis, advanced oxidation, membrane filtration, precipitation, etc. [7-10]. The adsorption has shown a good technique compared to other techniques because of its ease of operation, most effective method to remove dyes, high efficiency, low-energy requiring technology, availability of different adsorbents, effectiveness in regeneration, and reuse the adsorbent [11-18]. 
Agricultural solid wastes are low-cost materials and easily available adsorbents used by many researchers to remove the dyes from wastewaters according to their physic-chemical characteristics. Agricultural solid wastes contain main components: cellulose, lignin, hemicelluloses, lipids, proteins, etc. [19,20]. Besides are available and abundant in large quantities and have high potential sorbents due to the variety of functional groups $(-\mathrm{OH},-$ $\mathrm{C}=\mathrm{O},-\mathrm{C}-\mathrm{O}$, and $-\mathrm{NH}_{2}$ ) on their surface adsorbents [21]. As a result, agricultural solid wastes can be used as an economical and eco-friendly adsorbent since they are abundant and renewable sources [11,22]. Different adsorbents derived from agricultural solid wastes are used for the removal of dyes from an aqueous solution, such as date stones (Phoenix dactylifera) [23], jujube shells (Ziziphus lotus) [24], Clitoria fairchildiana [25], olive pomace [26], leaves of Platanus [27], walnut shell [28- 30], mandarin peel [31], banana peel [32], Eragrostis plana Nees [33], and waste of Citrus sinesis [34].

In this work, methylene blue (MB), Congo red (CR), and crystal violet (CV) are eliminated by the almond shell (AS) from an aqueous solution in single and binary systems. The almond is agricultural solid waste very abundant and available in our region used for pollutants removal in some other research. The performance of this material as a n adsorbent was limited due to its undeveloped porous structure [35-38]. The AS was characterized by Fourier transform infrared (FTIR) and scanning electron microscope (SEM) analysis. Furthermore, the key parameters affecting the dye adsorption in a single system, such as adsorbent dose, contact time, dye concentration, $\mathrm{pH}$ of the solution, and temperature, were evaluated. The MB, CV, and CR adsorption on AS was evaluated by kinetic (pseudo-first-order and pseudo-second-order) and isotherm (Langmuir and Freundlich and Temkin) models and thermodynamic parameters single system. Finally, the effectiveness of AS was tested for the removal of $\mathrm{MB}, \mathrm{CV}$, and $\mathrm{CR}$ from a binary mixture of $\mathrm{MB}+\mathrm{CR}, \mathrm{MB}+\mathrm{CV}$, and $\mathrm{CV}+\mathrm{CR}$.

\section{Meterails and Methods}

\subsection{Chemicals.}

Methylene blue (cationic dye, $\mathrm{C}_{16} \mathrm{H}_{18} \mathrm{ClN}_{3} \mathrm{~S}, \mathrm{CI}=52015, \mathrm{MW}=319.85 \mathrm{~g} \mathrm{~mol}^{-1}, \lambda_{\max }=661$ $\mathrm{nm}$ ), crystal violet (cationic dye, $\mathrm{C}_{25} \mathrm{H}_{30} \mathrm{~N}_{3} \mathrm{Cl}, \mathrm{CI}=42555, \mathrm{MW}=407.99 \mathrm{~g} \mathrm{~mol}^{-1}, \lambda_{\max }=584 \mathrm{~nm}$ ), Congo red (anionic dye, $\mathrm{C}_{32} \mathrm{H}_{22} \mathrm{~N}_{6} \mathrm{O}_{6} \mathrm{~S}_{2} \mathrm{Na}_{2}, \mathrm{CI}=22020, \mathrm{MW}=696.66 \mathrm{~g} \mathrm{~mol}^{-1}, \lambda_{\max }=498 \mathrm{~nm}$ ) sodium chloride $(\mathrm{NaCl})$, hydrochloric acid $(\mathrm{HCl})$, and sodium hydroxide $(\mathrm{NaOH})$ were of analytical grade and purchased from Sigma-Aldrich.

\subsection{Preparation and characterization of AS.}

The almond shells (AS) were collected in Agadir (South-West of Morocco). Those shells are washed several times with distilled water, then placed in an oven at $105^{\circ} \mathrm{C}$ for $24 \mathrm{~h}$, then ground on a laboratory mill Retsch SM10 and sieved to size 50-100 $\mu \mathrm{m}$ on laboratory sieve. The powder is conserved in a glass bottle and used for adsorbent test and analysis. The prepared adsorbent was characterized by Fourier transform infrared (FTIR) spectroscopy with resolution $4 \mathrm{~cm}^{-1}$ in a spectrometer Jasco 4100 and coupled with attenuated total reflectance (ATR) technique in the range $4000-400 \mathrm{~cm}^{-1}$ was used to determine the functional groups present in surface adsorbent, scanning electron microscope (SEM) on SUPRA $40 \mathrm{VP}$ at tension $20 \mathrm{kV}$ was utilized to specify the morphology of AS. The point of zero charges (PZC) value of AS was determined using the method reported by Fiol and Villaescusa [39]. 
2.3. Adsorption experiments.

2.3.1. Case of a single system.

The MB, CV, and CR sorption were conducted in $250 \mathrm{~mL}$ Erlenmeyer flasks on a thermostatic shaker in batch mode. A quantity of AS was added to $50 \mathrm{~mL}$ of dye solution (100 $\left.\mathrm{mg} \mathrm{L}^{-1}\right)$. The mixture was agitated at $170 \mathrm{rpm}$ at $22 \pm 1{ }^{\circ} \mathrm{C}$ for $10 \mathrm{~min}$. The influence of different parameters liked as AS dosage (4-40 $\left.\mathrm{g} \mathrm{L}^{-1}\right)$, contact time (0-120 min), initial dye concentration $\left(50-500 \mathrm{mg} \mathrm{L}^{-1}\right), \mathrm{pH}$ of the solution $(3-11)$, and temperature $\left(20-50{ }^{\circ} \mathrm{C}\right)$ on dyes adsorption was evaluated. The $\mathrm{pH}$ of the solution was adjusted by $0.1 \mathrm{M} \mathrm{HCl}$ or $0.1 \mathrm{M}$ sodium $\mathrm{NaOH}$. After completing the experiment, the dye solution was filtered through centrifuging at 3000 $\mathrm{rpm}$ for $10 \mathrm{~min}$. The concentrations of residual MB, CV, and CR were measured using a UV/Vis spectrophotometer (2300/Techcomp) at $661 \mathrm{~nm}, 584 \mathrm{~nm}$, and $498 \mathrm{~nm}$ as $\lambda_{\max }$ of MB, CV, and $\mathrm{CR}$, respectively. The quantity absorbed $q_{e}\left(\mathrm{mg} \mathrm{g}^{-1}\right)$ and removal efficiency (\%) of dye on AS were calculated by the equations given below:

$$
\begin{aligned}
& q_{e}=\frac{\left(C_{0}-C_{e}\right) \times V}{W} \\
& \% \text { Removal }=\frac{\left(C_{0}-C_{e}\right)}{C_{0}} \times 100
\end{aligned}
$$

where $C_{0}\left(\mathrm{mg} \mathrm{L}^{-1}\right)$ and $C_{e}\left(\mathrm{mg} \mathrm{L}^{-1}\right)$ are the dye concentrations before and after adsorption, respectively, $V(\mathrm{~L})$ is the dye solution volume, and $\mathrm{W}(\mathrm{g})$ is the weight of AS used.

\subsubsection{Case of the binary system.}

The binary mixtures of $\mathrm{MB}+\mathrm{CR}, \mathrm{MB}+\mathrm{CR}$, and $\mathrm{CV}+\mathrm{CR}$ were prepared with the percentage in volume ranging from 0 to $100 \%$ in $\mathrm{MB}, \mathrm{CV}$, and $\mathrm{CR}$, respectively. The final volume of the solution is still $50 \mathrm{~mL}$, and the initial concentrations are $100 \mathrm{mg} \mathrm{L}^{-1}$. Then, in each mixture, $0.4 \mathrm{~g}$ of adsorbent was added. The mixture is stirred magnetically for 15 min. After settling and centrifugation, the sample is analyzed using a spectrophotometer at the wavelength of the first dye and then at the wavelength of the second dye. For a system composed of two dyes $\mathrm{A}$ and $\mathrm{B}$, the concentration of $\mathrm{A}$ in the presence of $\mathrm{B}$ or $\mathrm{B}$ in the presence of $A$ is calculated using the equations (3) and (4), respectively [10,40-41]:

$$
\begin{aligned}
C_{A} & =\frac{K_{B, 2} a_{1}-K_{B, 1} a_{2}}{K_{A, 1} K_{B, 2}-K_{A, 2} K_{A, 1}} \\
C_{B} & =\frac{K_{A, 1} a_{2}-K_{A, 2} a_{1}}{K_{A, 1} K_{B, 2}-K_{A, 2} K_{A, 1}}
\end{aligned}
$$

where $\mathrm{C}_{A}\left(\mathrm{mg} \mathrm{L}^{-1}\right)$ and $C_{B}\left(\mathrm{mg} \mathrm{L}^{-1}\right)$ are the concentrations of $\mathrm{A}$ and $\mathrm{B}$ in binary solution, respectively, $K_{A, 1}, K_{A, 2}, K_{B, 1}$, and $K_{B, 2}$ are the slopes of calibration curve for A to $\lambda_{1}$ (maximum wavelength for the dye (A)) and $\lambda_{2}$ (maximum wavelength for the dye (B)), for B to $\lambda_{1}$ and $\lambda_{2}$. And $\mathrm{a}_{1}$ and $\mathrm{a}_{2}$ are absorbance values measured respectively at $\lambda_{1}$ and $\lambda_{2}$. 


\subsection{Error analysis.}

The validity of each model of kinetic and isotherm adsorption was analyzed by the residual root-mean-square error (RMSE), the sum squares error (SSE), and the Marquardt's percent standard deviation $(M P S D)$ and were calculated from the following equations (5), (6), and (7), respectively $[42,43]$ :

$$
\begin{gathered}
\text { RMSE }=\sqrt{\sum_{i=1}^{N} \frac{\left(q_{e, \text { exp }}-q_{e, c a l}\right)^{2} i}{N}} \\
S S E=\sum_{i=1}^{N}\left(q_{e, \text { exp }}-q_{e, \text { cal }}\right)^{2} i \\
M P S D=\sqrt{\sum_{i=1}^{N} \frac{\left(q_{e, \text { exp }}-q_{e, c a l}\right)^{2} i}{\left(q_{e, \text { exp }}\right) i}}
\end{gathered}
$$

where $N$ is the number of experimental points.

\section{Results and Discussion}

\subsection{FTIR and SEM analysis.}

Infrared spectroscopy helps us to a better comprehension of the functional group on the surface of the adsorbent. The FTIR spectrum of AS is shown in Figure 1. The broadband at $3345 \mathrm{~cm}^{-1}$ corresponds to the elongation of the $\mathrm{O}-\mathrm{H}$ groups fond on cellulose hemicelluloses and lignin [44,45], the band at approximately $2915 \mathrm{~cm}^{-1}$ is attributed to $-\mathrm{C}-\mathrm{H}$ stretching $[23,46,47]$, the bands at $1718 \mathrm{~cm}^{-1}$ and $1626 \mathrm{~cm}^{-1}$ represent stretching vibrations of $-\mathrm{C}=\mathrm{O}$ of esters and acids [48,49] and aromatic $-\mathrm{C}=\mathrm{C}[15]$, respectively. The peaks at $1454 \mathrm{~cm}^{-1}, 1245$ $\mathrm{cm}^{-1}$, and $1021 \mathrm{~cm}^{-1}$ are attributed to aliphatic $-\mathrm{C}-\mathrm{O}-\mathrm{C},-\mathrm{C}-\mathrm{O}-\mathrm{H},-\mathrm{C}-\mathrm{O}$ stretching, respectively [50-52]. SEM images of AS were shown in Figure 2. From Figure 2, the AS has a heterogeneous surface, porous, and micropores, as seen from its surface micrographs. Those pores favor the adsorption of dye.

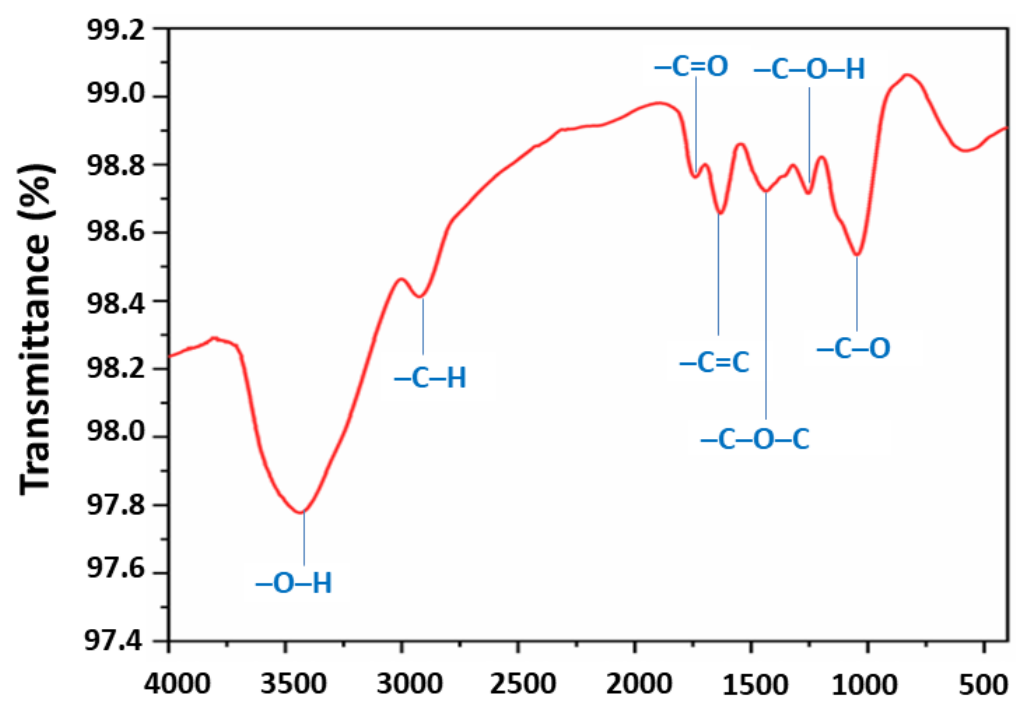

Wavenumber $\left(\mathrm{cm}^{-1}\right)$

Figure 1. FTIR of AS. 

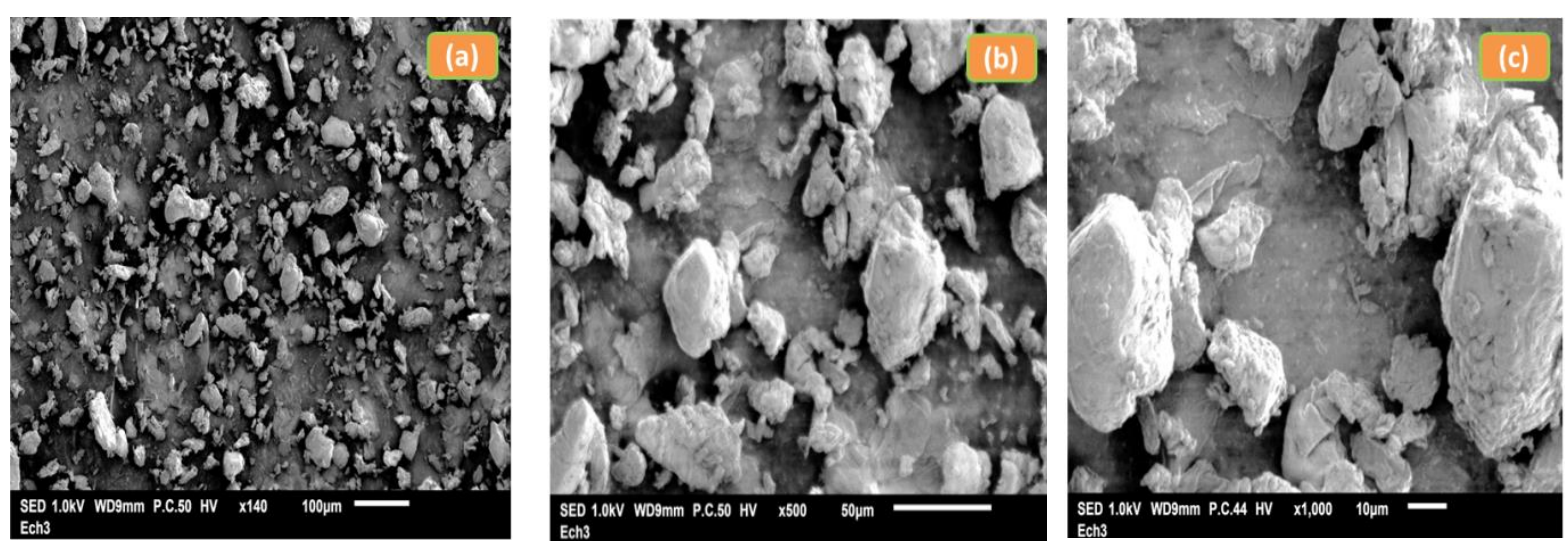

Figure 2. SEM images of AS: (a) 140X; (b) 500X; (c) 1000X.

\subsection{Adsorption study in a single system.}

\subsubsection{Effect of AS dose.}

To evaluate AS dosage's effect, the adsorption experiments were carried out with different dosages of 4 to $40 \mathrm{~g} \mathrm{~L}^{-1}$. In contrast, other parameters keep constant (MB, CV or CR dye concentration $=100 \mathrm{mg} \mathrm{L}^{-1}$, contact time $=60 \mathrm{~min}, \mathrm{pH}(\mathrm{MB})=5.57, \mathrm{pH}(\mathrm{CV})=5.46$ and $\mathrm{pH}(\mathrm{CR})=6.08)$. As Figure 3 shows, $\mathrm{MB}$ and $\mathrm{CV}$ removal increase from 92.83 to $98.77 \%$ and 84.67 to $98.55 \%$ by increasing the adsorbent dosage from 4 to $8 \mathrm{~g} \mathrm{~L}^{-1}$, respectively, while CR removal increase from 61.25 to $93.12 \%$ by increasing the adsorbent dosage from 4 to $20 \mathrm{~g} \mathrm{~L}^{-1}$. The results imply that the number of active adsorption sites for $\mathrm{MB}, \mathrm{CV}$, and $\mathrm{CR}$ adsorption corresponds to the applied dose prompts higher removal efficiency [53]. After equilibrium between the adsorbent and dye in the solution, the removal percentage remains consistent at higher dosages ( $>8 \mathrm{~g} \mathrm{~L}^{-1}$ for $\mathrm{MB}$ and $\mathrm{CV}$ ). After a ratio of $20 \mathrm{~g} \mathrm{~L}^{-1}$, we note a slight decrease of CR removal due to saturation of active adsorption sites on the surface of AS. The optimum adsorbent dosage was considered $8 \mathrm{~g} \mathrm{~L}^{-1}$ for $\mathrm{MB}$ and $20 \mathrm{~g}$ $\mathrm{L}^{-1}$ for $\mathrm{CR}$ to reach maximum dye removal efficiency.

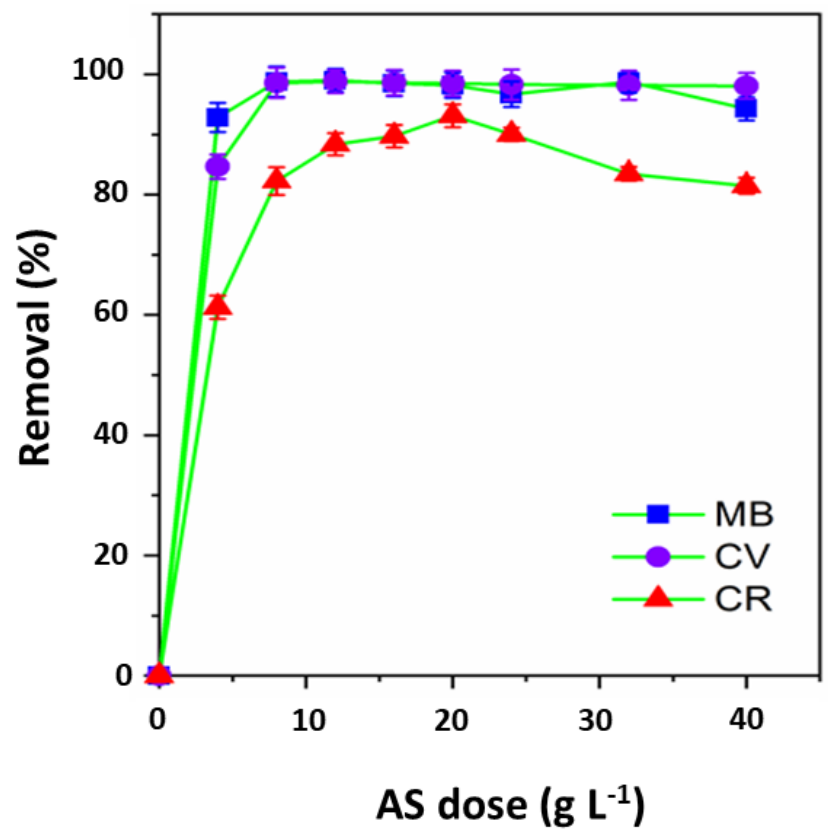

Figure 3. Effect of AS dose on $\mathrm{MB}, \mathrm{CV}$ and $\mathrm{CR}$ adsorption $\left(\mathrm{t}=60 \mathrm{~min}, C_{0}=100 \mathrm{mg} \mathrm{L}^{-1}, T=22 \pm 1{ }^{\circ} \mathrm{C}, \mathrm{pH}\right.$ $(\mathrm{MB})=5.57, \mathrm{pH}(\mathrm{CV})=5.46, \mathrm{pH}(\mathrm{CR})=6.08)$. 


\subsubsection{Time effect and kinetic study.}

Figure 4 illustrates the effect of contact time on the removal of $\mathrm{MB}, \mathrm{CV}$, and $\mathrm{CR}$ on $\mathrm{AS}$, for operating conditions with an initial concentration of $100 \mathrm{mg} \mathrm{L}^{-1}$ of dye and $8 \mathrm{~g} \mathrm{~L}^{-1}$ for $\mathrm{MB}$ and $\mathrm{CV}$ and $20 \mathrm{~g} \mathrm{~L}^{-1}$ for $\mathrm{CR}$ of AS dosage at a temperature of $22 \pm 1{ }^{\circ} \mathrm{C}$, and a contact time ranging from 0 to $120 \mathrm{~min}$. The results obtained are regrouped in Figure 4. This figure shows that the adsorption of $\mathrm{MB}, \mathrm{CV}$, and $\mathrm{CR}$ on $\mathrm{AS}$ has two phases, a rapid initial phase in which the quantity adsorbed increases strongly during the first 10 minutes, it may be justified by adsorption on the external surface and many sites that are accessible on the surface of the adsorbent in the initial stage [54]. A second phase, slower with a low contribution to the total adsorption of dye and corresponds to adsorption on the internal surface of adsorbent also due to decreasing in several active sites on the surface of adsorbent the $[55,56]$.

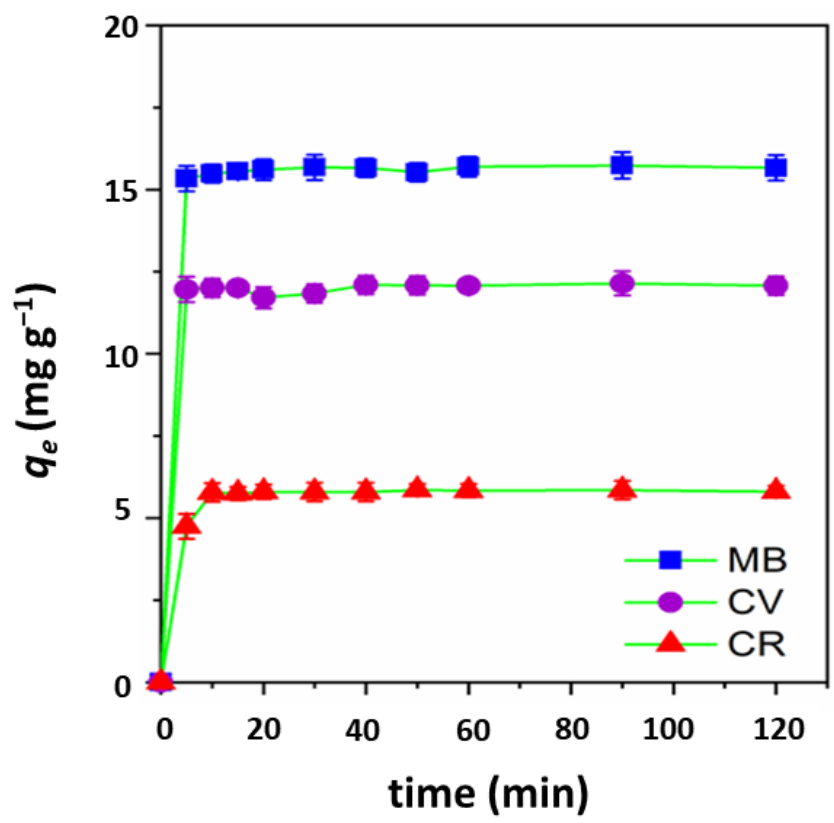

Figure 4. Effect of contact time on $\mathrm{MB}, \mathrm{CV}$ and $\mathrm{CR}$ adsorption. (AS dose $(\mathrm{MB})=8 \mathrm{~g} \mathrm{~L}^{-1}$, AS dose $(\mathrm{CV})=8 \mathrm{~g}$ $\mathrm{L}^{-1}$, AS dose $\left.(\mathrm{CR})=20 \mathrm{~g} \mathrm{~L}^{-1}, \mathrm{pH}(\mathrm{MB})=5.57, \mathrm{pH}(\mathrm{CV})=5.46, \mathrm{pH}(\mathrm{CR})=6.08, C_{0}=100 \mathrm{mg} \mathrm{L}^{-1}, T=22 \pm 1{ }^{\circ} \mathrm{C}\right)$.

The experimental data were analyzed by pseudo-first-order and pseudo-second-order kinetic models and are expressed by the equations below [23,57]:

$$
\begin{aligned}
& \log \left(q_{e}-q_{t}\right)=\log \left(q_{e}\right)-\frac{K_{1}}{2.303} t \\
& \frac{t}{q_{t}}=\frac{1}{K_{2} q_{e}{ }^{2}}+\frac{1}{q_{e}} t
\end{aligned}
$$

where $q_{t}\left(\mathrm{mg} \mathrm{g}^{-1}\right)$ and $q_{e}\left(\mathrm{mg} \mathrm{g}^{-1}\right)$ are the amounts adsorbed at $t$ and equilibrium, respectively, $t$ is the time of reaction, $K_{1}\left(\mathrm{~min}^{-1}\right)$ and $K_{2}\left(\mathrm{~g} \mathrm{mg}^{-1} \mathrm{~min}^{-1}\right)$ are the constants related to the firstorder and second-order, respectively. The kinetic parameters of each model and the margins of error between the calculated and measured values are summarized in Table 1. By comparing the values of $r^{2}$ and the errors obtained for the kinetics of the pseudo-first-order with those of the pseudo-second-order, it can easily be concluded that the current reaction takes place via a mechanism of pseudo-second-order rather than a mechanism of pseudo-first-order. 
Table 1. Kinetic model parameters for adsorption of $\mathrm{MB}, \mathrm{CV}$, and $\mathrm{CR}$ on $\mathrm{AS}$.

\begin{tabular}{l|l|l|l|l} 
Model & Parameter & MB & CV & CR \\
\hline \multirow{5}{*}{ Pseudo-first-order } & $q_{e, \text { exp }}\left(\mathrm{mg} \mathrm{g}^{-1}\right)$ & 15.23 & 12.11 & 5.77 \\
\cline { 2 - 5 } & $q_{e, \text { cal }}\left(\mathrm{mg} \mathrm{g}^{-1}\right)$ & 0.30 & 0.17 & 0.07 \\
\cline { 2 - 5 } & $K_{l}\left(\mathrm{~min}^{-1}\right)$ & 0.038 & 0.008 & 0.011 \\
\cline { 2 - 5 } & $r^{2}$ & 0.904 & 0.380 & 0.364 \\
\cline { 2 - 5 } & $R M S E$ & 15.299 & 11.822 & 5.730 \\
\cline { 2 - 5 } & $S E E$ & 25.745 & 81.671 & 38.341 \\
\cline { 2 - 5 } & $M P S D$ & 0.961 & 0.9708 & 0.974 \\
\hline \multirow{5}{*}{ Pseudo-second-order } & $q_{e, \text { cal }}\left(\mathrm{mg} \mathrm{g}^{-1}\right)$ & 15.74 & 12.10 & 5.82 \\
\cline { 2 - 5 } & $K_{2}\left(\mathrm{~g} \mathrm{mg}^{-1} \mathrm{~min}^{-1}\right)$ & 0.517 & 0.429 & 4.832 \\
\cline { 2 - 5 } & $r^{2}$ & 0.999 & 0.999 & 0.999 \\
\cline { 2 - 5 } & $R M S E$ & 0.185 & 0.173 & 0.037 \\
\cline { 2 - 5 } & $S E E$ & 0.377 & 0.386 & 0.013 \\
\cline { 2 - 5 } & $M P S D$ & 0.007 & 0.001 & 0.002
\end{tabular}

3.2.3. Effect of dye concentration and adsorption equilibrium.

The effect of initial MB, CV, and CR concentrations varied from 50 to $500 \mathrm{mg} \mathrm{L}^{-1}$ with keeping all other parameters consistent $\left(\mathrm{AS}\right.$ dose $(\mathrm{MB})=8 \mathrm{~g} \mathrm{~L}^{-1}$, AS dose $(\mathrm{CV})=8 \mathrm{~g} \mathrm{~L}^{-1}$, AS dose $(\mathrm{CR})=20 \mathrm{~g} \mathrm{~L}^{-1}$, temperature: $22 \pm 1^{\circ} \mathrm{C}$, contact time: $10 \mathrm{~min}$. The results are depicted in Figure 5. The adsorption capacity progressively increased with increasing $\mathrm{CR}$ and $\mathrm{MB}$ concentrations 50 to $500 \mathrm{mg} \mathrm{L}^{-1}$ due to the occupation of all available active sites in the surface of the adsorbent by MB, CV, and CR molecules [58].

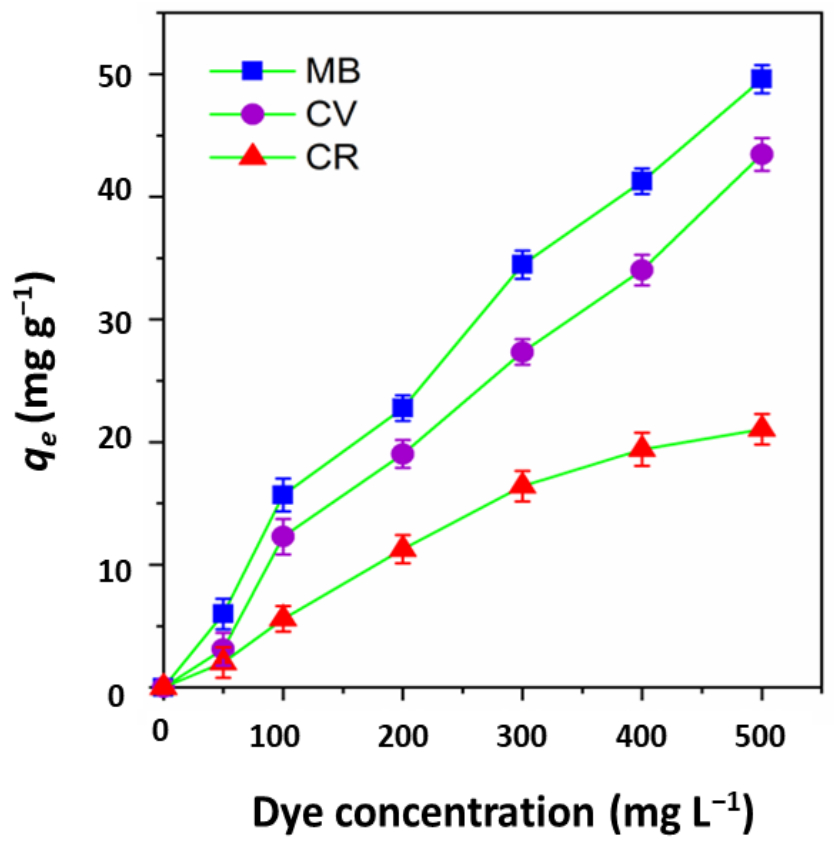

Figure 5. Effect dye concentration on $\mathrm{MB}, \mathrm{CV}$ and $\mathrm{CR}$ adsorption $\left(\mathrm{AS}\right.$ dose $(\mathrm{MB})=8 \mathrm{~g} \mathrm{~L}{ }^{-1}$, AS dose $(\mathrm{CV})=8 \mathrm{~g}$ $\mathrm{L}^{-1}, \mathrm{AS}$ dose $\left.(\mathrm{CR})=20 \mathrm{~g} \mathrm{~L}^{-1}, \mathrm{pH}(\mathrm{MB})=5.57, \mathrm{pH}(\mathrm{CV})=5.46, \mathrm{pH}(\mathrm{CR})=6.08, t=10 \mathrm{~min}, T=22 \pm 1^{\circ} \mathrm{C}\right)$.

The experimental data at the equilibrium of $\mathrm{MB}, \mathrm{CV}$, and $\mathrm{CR}$ on $\mathrm{AS}$ were fitted to Langmuir and Freundlich isotherm models and are represented by the equations below, respectively [59-61]:

$$
\begin{aligned}
& \frac{C_{e}}{q_{e}}=\frac{1}{Q_{m} K_{L}}+\frac{C_{e}}{Q_{m}} \\
& L n q_{e}=\operatorname{Ln} K_{F}+\frac{\operatorname{Ln} C_{e}}{n}
\end{aligned}
$$




$$
q_{e}=B \operatorname{Ln} K_{T}+B \operatorname{Ln} C_{e}
$$

where $Q_{m}\left(\mathrm{mg} \mathrm{g}^{-1}\right)$ is the maximum dye per gram of adsorbent, $K_{L}\left(\mathrm{~L} \mathrm{mg}^{-1}\right)$ is the constant of Langmuir isotherm, $K_{F}\left(\left(\mathrm{mg} \mathrm{g}^{-1}\right)\left(\mathrm{L} \mathrm{mg}^{-1}\right)^{1 / \mathrm{n}}\right)$ is the constant related to Freundlich isotherm, $K_{T}\left(\mathrm{~L} \mathrm{~g}^{-1}\right)$ is the constant of Temkin isotherm and $B$ is the constant related to the heat adsorption. The calculated parameters are given in Table 2. Based on correlation coefficient $r^{2}$, the Langmuir model best described the MB, CV, and CR adsorption equilibrium data. Langmuir model suggests the dye adsorption occurs as a monolayer from the homogeneous surface of the adsorbent [62].

Table 2. Isotherm model parameters for adsorption of MB, CV, and CR on AS.

\begin{tabular}{l|l|l|l|l} 
Model & Parameter & MB & CV & CR \\
\hline \multirow{5}{*}{ Langmuir } & $Q_{m}\left(\mathrm{mg} \mathrm{g}^{-1}\right)$ & 52.35 & 44.78 & 26.92 \\
\cline { 2 - 5 } & $K_{L}\left(\mathrm{~L} \mathrm{mg}^{-1}\right)$ & 71.252 & 127.291 & 28.6 \\
\cline { 2 - 5 } & $r^{2}$ & 0.992 & 0.991 & 0.994 \\
\cline { 2 - 5 } & $R M S E$ & 4.202 & 2.808 & 1.1265 \\
\cline { 2 - 5 } & $S E E$ & 123.651 & 7.312 & 10.058 \\
\cline { 2 - 5 } & $M P S D$ & 0.018 & 0.020 & 0.008 \\
\hline \multirow{5}{*}{ Freundlich } & $K_{F}\left(\left(\mathrm{mg} \mathrm{g}^{-1}\right)\left(\mathrm{L} \mathrm{mg}^{-1}\right)^{1 / \mathrm{n}}\right)$ & 9.021 & 8.65 & 1.851 \\
\cline { 2 - 5 } & $N$ & 4.672 & 2.841 & 2.011 \\
\cline { 2 - 5 } & $r^{2}$ & 0.845 & 0.900 & 0.873 \\
\cline { 2 - 5 } & $R M S E$ & 188.646 & 116.91 & 2.8249 \\
\cline { 2 - 5 } & $S E E$ & 14.355 & 12.845 & 47.879 \\
\cline { 2 - 5 } & $M P S D$ & 0.964 & 0.1889 & 0.1954 \\
\hline \multirow{5}{*}{ Temkin } & $B$ & 1.327 & 2.893 & 0.370 \\
\cline { 2 - 5 } & $K_{T}\left(\mathrm{~L} \mathrm{~g}{ }^{-1}\right)$ & 9.125 & 7.191 & 5.342 \\
\cline { 2 - 5 } & $r^{2}$ & 0.936 & 0.987 & 0.972 \\
\cline { 2 - 5 } & $R M S E$ & 3.943 & 3.557 & 1.313 \\
\cline { 2 - 5 } & $S E E$ & 124.53 & 14.55 & 10.354 \\
\cline { 2 - 5 } & $M P S D$ & 0.0233 & 0.040 & 0.001 \\
\cline { 2 - 5 } & & &
\end{tabular}

\subsubsection{Effect of $\mathrm{pH}$.}

Figure 6 illustrates the removal of $\mathrm{MB}, \mathrm{CV}$, and $\mathrm{CR}$ dyes as a function of solution $\mathrm{pH}$. The batch experiments were conducted at different $\mathrm{pH}$ ranging from 3 to 11 at an initial concentration of $100 \mathrm{mg} \mathrm{L}^{-1}$ of dye. The point of zero charges (PZC) is a crucial parameter to understand the adsorption process. As Figure 7 depicted, PZC of AS was 5.7. From Figure 6, it can be noted that the adsorption capacity of $\mathrm{MB}$ and $\mathrm{CV}$ increased from 6.43 to $15.15 \mathrm{mg}$ $\mathrm{g}^{-1}$ and from 4.43 to $12.15 \mathrm{mg} \mathrm{g}^{-1}$ when the $\mathrm{pH}$ of the solution increased from 3 to 11 , respectively, while the adsorption capacity of CR decreased from 5.83 to $2.78 \mathrm{mg} \mathrm{g}^{-1}$. The unfavorable adsorption of $\mathrm{MB}$ and $\mathrm{CV}$, the favorable adsorption of $\mathrm{CR}$ in an acidic medium due to the positive charge of AS surface at $\mathrm{pH}<\mathrm{PZC}$, when $\mathrm{pH}>\mathrm{PZC}$, and the adsorption of $\mathrm{MB}$ and $\mathrm{CV}$ are favorable and unfavorable for $\mathrm{CR}$ due to the negative charge of surface adsorbent $[63,64]$. 


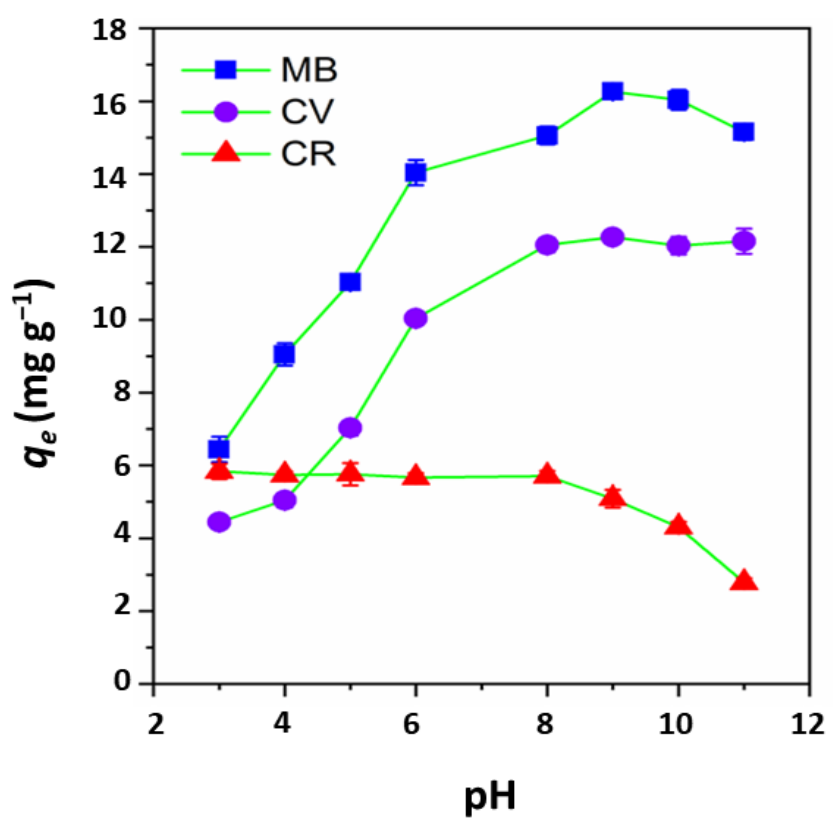

Figure 6. Effect $\mathrm{pH}$ on $\mathrm{MB}, \mathrm{CV}$, and $\mathrm{CR}$ adsorption $\left(\mathrm{AS}\right.$ dose $(\mathrm{MB})=8 \mathrm{~g} \mathrm{~L}^{-1}$, AS dose $(\mathrm{CV})=8 \mathrm{~g} \mathrm{~L}{ }^{-1}$, AS dose $\left.(\mathrm{CR})=20 \mathrm{~g} \mathrm{~L}^{-1}, C_{0}=100 \mathrm{mg} \mathrm{L}^{-1}, t=10 \mathrm{~min}, T=22 \pm 1^{\circ} \mathrm{C}\right)$.

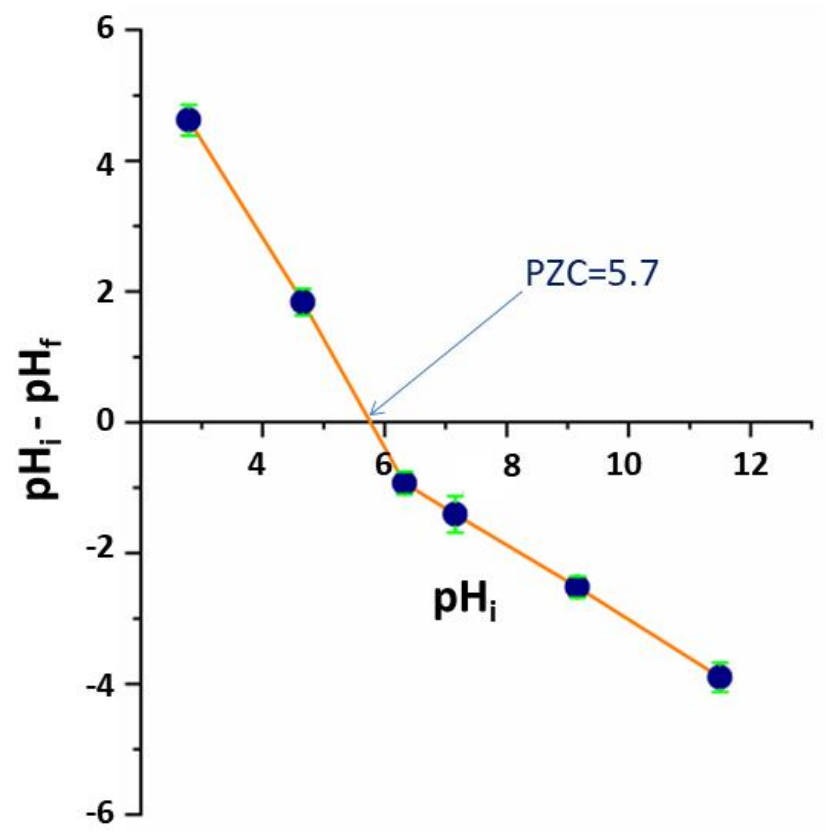

Figure 7. PZC of AS.

3.2.5. Effect of temperature and thermodynamic adsorption.

The effect of temperature of $\mathrm{MB}, \mathrm{CV}$, and $\mathrm{CR}$ adsorption on $\mathrm{AS}$ was studied at the ranging temperature $20-50{ }^{\circ} \mathrm{C}$ using $8 \mathrm{~g} \mathrm{~L}^{-1}$ for $\mathrm{MB}\left(100 \mathrm{mg} \mathrm{L}^{-1}\right)$ or $8 \mathrm{~g} \mathrm{~L}^{-1}$ for $\mathrm{CV}(100 \mathrm{mg}$ $\left.\mathrm{L}^{-1}\right)$ or $20 \mathrm{~g} \mathrm{~L}^{-1}$ for $\mathrm{CR}\left(100 \mathrm{mg} \mathrm{L}^{-1}\right)$ of AS dosage and contact time of $10 \mathrm{~min}$. The results are presented in Figure 8. It was seen that when the temperature was increased from 20 to $50{ }^{\circ} \mathrm{C}$, the adsorption capacity of dye decreased from 15.68 to $15.28 \mathrm{mg} \mathrm{g}^{-1}$ for $\mathrm{MB}$, from 12.04 to $8.82 \mathrm{mg} \mathrm{g}^{-1}$ for $\mathrm{CV}$, and from 5.58 to $3.87 \mathrm{mg} \mathrm{g}^{-1}$ at $\mathrm{pH}=5.57, \mathrm{pH}=5.46$ and $\mathrm{pH}=6.08$ for $\mathrm{MB}, \mathrm{CV}$, and CR, respectively. This decrease of the adsorption capacity due to the mobility of no accelerated dye molecules increases the temperature [65]. 


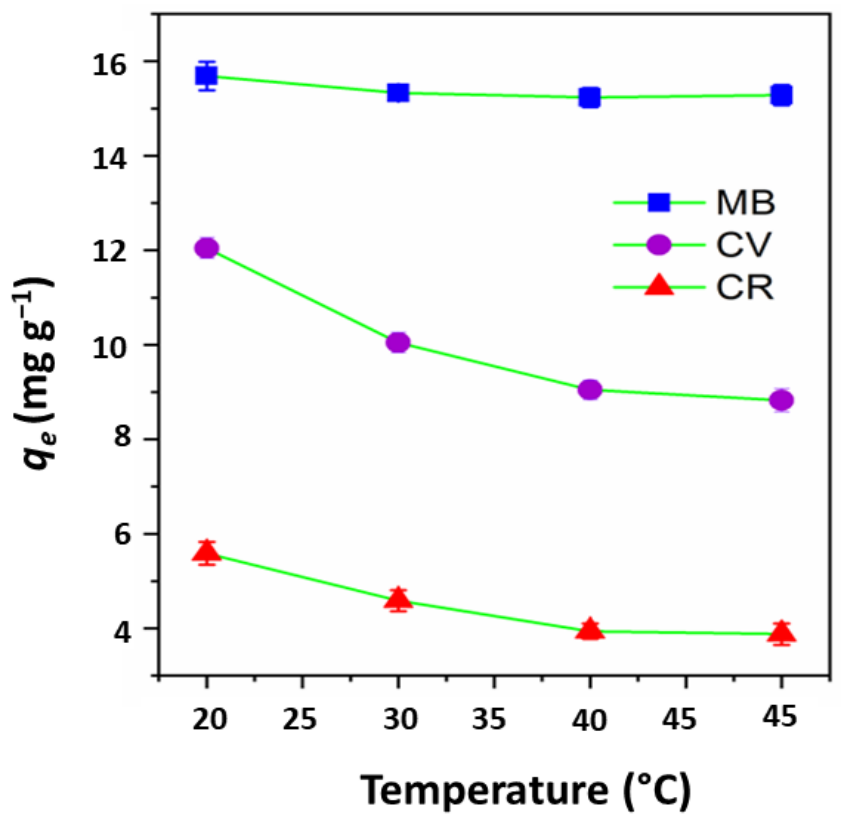

Figure 8. Effect temperature on $\mathrm{MB}, \mathrm{CV}$ and $\mathrm{CR}$ adsorption (AS dose $(\mathrm{MB})=8 \mathrm{~g} \mathrm{~L}^{-1}, \mathrm{AS}$ dose $(\mathrm{CV})=8 \mathrm{~g} \mathrm{~L}-1$, $\mathrm{AS}$ dose $\left.(\mathrm{CR})=20 \mathrm{~g} \mathrm{~L}^{-1}, \mathrm{pH}(\mathrm{MB})=5.57, \mathrm{pH}(\mathrm{CV})=5.46, \mathrm{pH}(\mathrm{CR})=6.08, t=10 \mathrm{~min}, C_{0}=100 \mathrm{mg} \mathrm{L}^{-1}\right)$.

The thermodynamic parameters as the free energy $\Delta G^{\circ}$, the enthalpy $\Delta H^{\circ}$, and the entropy $\triangle S^{\circ}$ of $\mathrm{MB}, \mathrm{CV}$, and $\mathrm{CR}$ adsorption on the $\mathrm{AS}$ were calculated by the equations below [66]:

$$
\begin{aligned}
& \Delta G^{\circ}=-R T \operatorname{Ln} K_{C} \\
& L n K_{C}=\frac{\Delta S^{\circ}}{R}-\frac{\Delta H^{\circ}}{R T}
\end{aligned}
$$

where $R\left(8.314 \mathrm{~J} \mathrm{~mol}^{-1} \mathrm{~K}^{-1}\right)$ is the constant of perfect gases, $T(\mathrm{~K})$ is the absolute temperature, and, $K_{C}$ is the equilibrium constant, $\Delta H^{\circ}$ was obtained from the slope of $L n K_{C}$ versus $1 / T\left(\mathrm{~K}^{-}\right.$ ${ }^{1}$ ), and $\Delta S^{\circ}$ was obtained from y-intercept for adsorption of dye. The thermodynamic parameters of MB, CV, and CR adsorption on AS are given in Table 3. The negative value of $\Delta G^{\circ}$ at five temperatures suggested the feasibility and spontaneity of the $\mathrm{MB}, \mathrm{CV}$, and $\mathrm{CR}$ adsorption on AS [67]. This adsorption is physical because the $\Delta G^{\circ}$ was lower than $0 \mathrm{~kJ} \mathrm{~mol}^{-1}$ [68]. The negative $\Delta H^{\circ}$ values verified the exothermic nature of the adsorption process [69]. The negative $\Delta S^{\circ}$ values indicate that the disorder decreases at the adsorbent/solution interface [70].

\begin{tabular}{|c|c|c|c|c|}
\hline Dye & $T(\mathbf{K})$ & $\Delta G^{\circ}\left(\mathrm{kJ} \mathrm{mol}^{-1}\right)$ & $\Delta H^{\circ}\left(\mathrm{kJ} \mathrm{mol}^{-1}\right)$ & $\Delta S^{\circ}\left(\mathrm{J} \mathrm{mol}^{-1} \mathrm{~K}^{-1}\right)$ \\
\hline \multirow{4}{*}{ MB } & 293 & -10.425 & \multirow{4}{*}{-12.191} & \multirow{4}{*}{-5.881} \\
\hline & 300 & -10.346 & & \\
\hline & 313 & -10.204 & & \\
\hline & 323 & -08.753 & & \\
\hline \multirow[t]{4}{*}{$\mathrm{CV}$} & 293 & -11.934 & \multirow{4}{*}{-17.461} & \multirow{4}{*}{-18.984} \\
\hline & 300 & -11.452 & & \\
\hline & 313 & -11.007 & & \\
\hline & 323 & -10.337 & & \\
\hline \multirow[t]{4}{*}{$\mathrm{CR}$} & 293 & -05.850 & \multirow{4}{*}{-06.805} & \multirow{4}{*}{-21.201} \\
\hline & 300 & -04.461 & & \\
\hline & 313 & -03.821 & & \\
\hline & 323 & -02.478 & & \\
\hline
\end{tabular}

Table 3. The thermodynamic parameters of $\mathrm{MB}, \mathrm{CV}$, and $\mathrm{CR}$ adsorption on AS. 
3.2.6. Proposed adsorption mechanism of dyes onto the adsorbent.

The adsorption mechanism of $\mathrm{MB}, \mathrm{CV}$, and $\mathrm{CR}$ onto the surface of $\mathrm{AS}$ is proposed based on FTIR analysis and PZC of the adsorbent. From this figure, the MB and CV adsorption onto adsorbent are interactions such as hydrogen bonding and electrostatic interaction in case of $\mathrm{pH}<\mathrm{PZC}$ and hydrogen bonding and electrostatic repulsion in case of $\mathrm{pH}>\mathrm{PZC}$ between the CR dye molecules and surface AS, unlike in the case of CR [71-74].

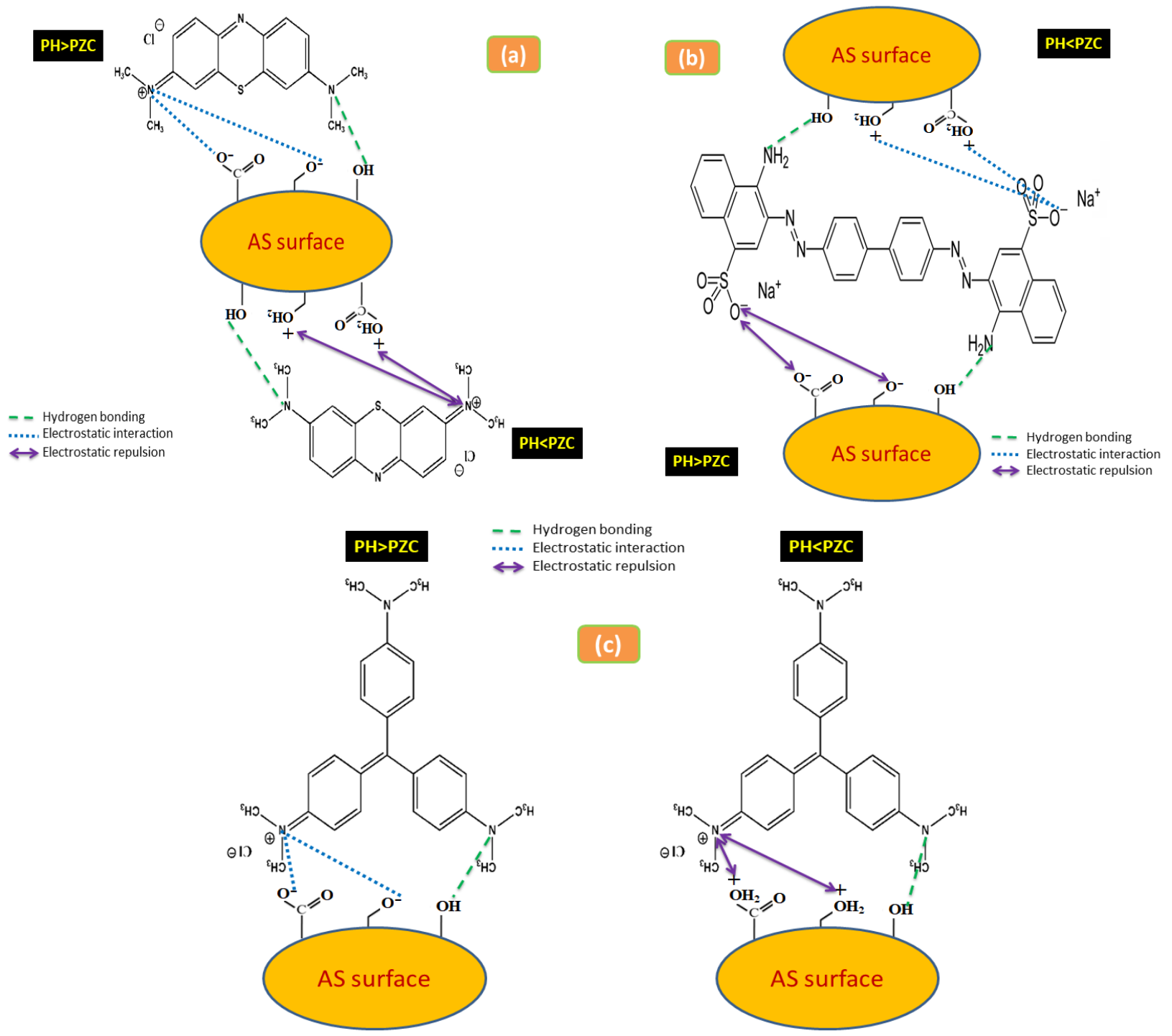

Figure 9. Proposed adsorption mechanism of (a) MB; (b) CR; (c) CV onto AS.

\subsection{Adsorption study in a binary system.}

\subsubsection{Mixture of MB with $\mathrm{CR}$.}

The adsorption of $\mathrm{MB}$ and $\mathrm{CR}$ from $\mathrm{MB}+\mathrm{CR}$ was tested and the results obtained are shown in Figure 10. Analysis of these results shows that MB adsorption is almost independent of the presence of $\mathrm{CR}$, while the presence of MB strongly influences the adsorption of $\mathrm{CR}$. Indeed, the amount of adsorbed CR increased from 8.23 to $12.10 \mathrm{mg} \mathrm{g}^{-1}$ in the presence of $\mathrm{MB}$ from 0 to $80 \%$ in the mixture $\mathrm{MB}+\mathrm{CR}$. An electrostatic attraction generally explains this improvement in the amount of adsorbed between MB (adsorbed to a solid surface), which is cationic, and CR (free in the solution), which is anionic, as shown in Figure 11 [1,75]. CR molecules adsorbed on AS offer a new opportunity for adsorption for some MB molecules not 
yet adsorbed. In this mixture, a phenomenon of synergy between dyes was reported by Komal Sharma et al. [76].

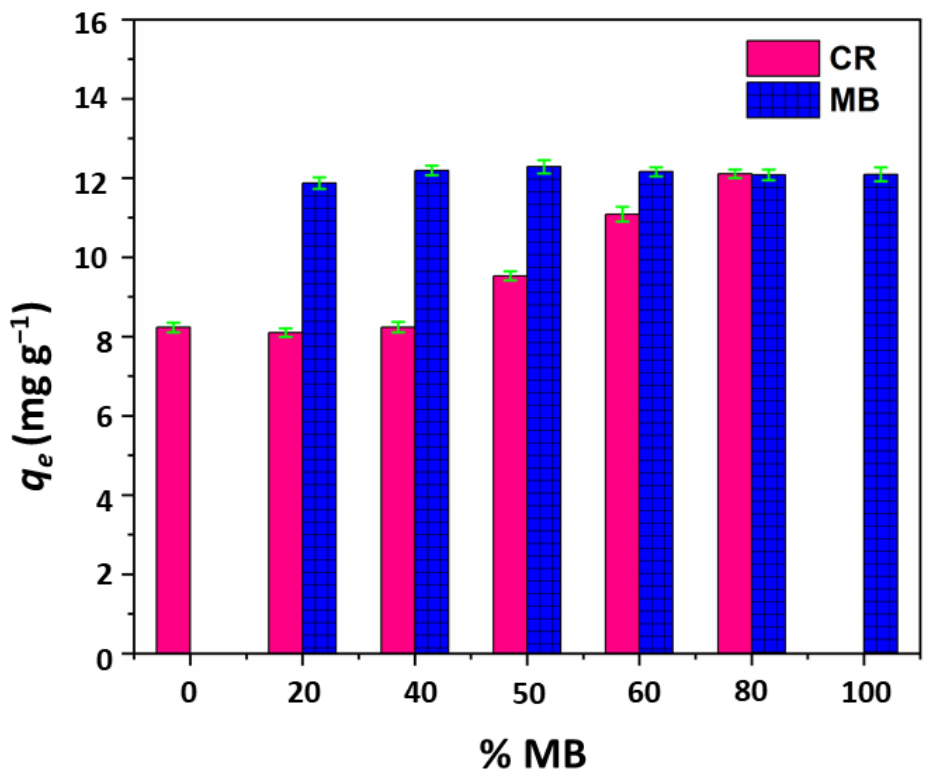

Figure 10. Adsorption of $\mathrm{MB}$ and $\mathrm{CR}$ from a binary mixture of $\mathrm{MB}+\mathrm{CR}$ using $\mathrm{AS}\left(\mathrm{AS}\right.$ dose $=8 \mathrm{mg} \mathrm{L} \mathrm{L}^{-1}, t=15$ $\left.\min , T=22 \pm 1^{\circ} \mathrm{C}\right)$.

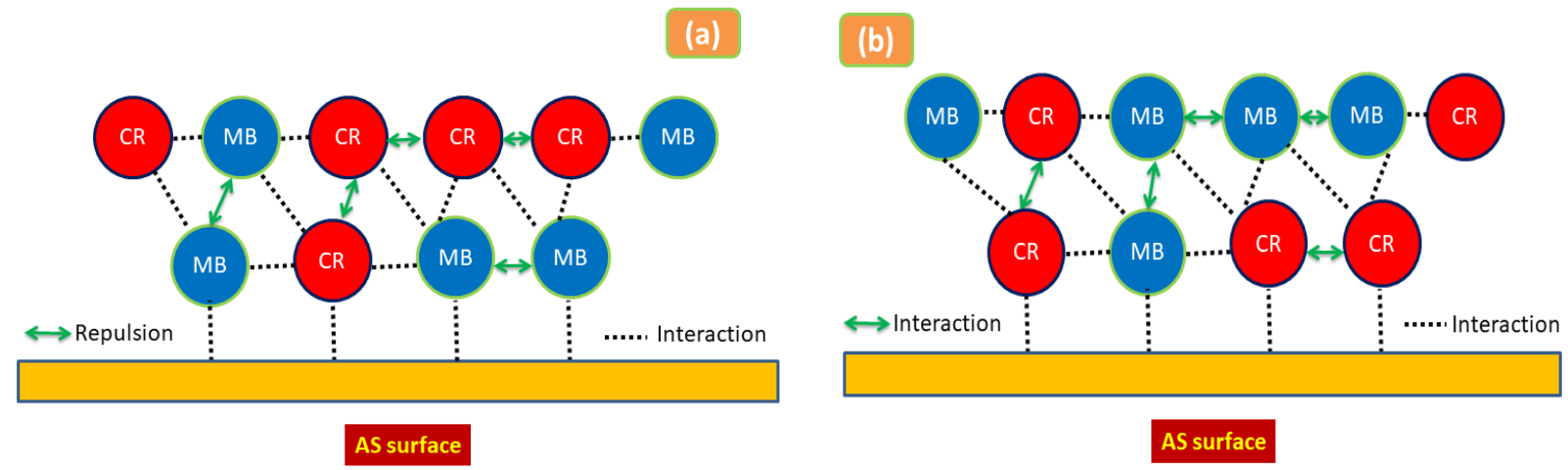

Figure 11. Proposed mechanism of adsorption of MB+CR onto AS: (a) CR majority; (b) CR minority.

\subsubsection{Mixture of MB with CV.}

This study focuses on elucidating the effect of a cationic dye (methylene blue) on the adsorption of another cationic dye (crystal violet). For this, we realized $\mathrm{CV}$ adsorption tests on AS in the presence of different percentages of MB. Figure 12 shows obtained results. These results show two remarkable points: The first is the slight decrease in the adsorbed amount of $\mathrm{MB}$ and $\mathrm{CV}$ in the mixture compared to that obtained in the case of the single system (100\%). This remark is also reported by other authors [10,41,77], who propose as an explanation that the presence of another ionic dye of the same charge in the solution creates competition (antagonistic effect) for adsorption sites on the adsorbent surface. The second point was remarked in all mixtures; it is the minority dye that adsorbs more may be justified by accentuating the steric effect between the adsorbed molecules and not adsorbed with increased concentration. This steric effect plays the role of a repulsive force that inhibits the adsorption of high-concentration dye [75]. These two effects are summarized in Figure 13. 


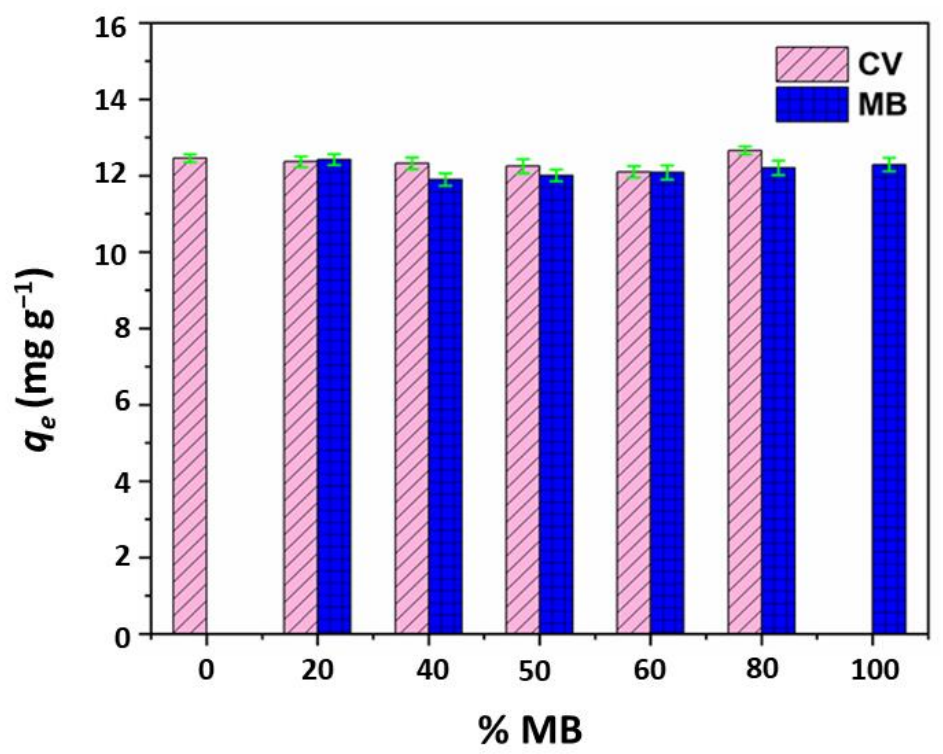

Figure 12. Adsorption of $\mathrm{MB}$ and $\mathrm{CV}$ from a binary mixture of $\mathrm{MB}+\mathrm{CV}$ using $\mathrm{AS}$ (AS dose $=8 \mathrm{~g} \mathrm{~L}^{-1}, t=15$ $\left.\min , T=22 \pm 1^{\circ} \mathrm{C}\right)$.

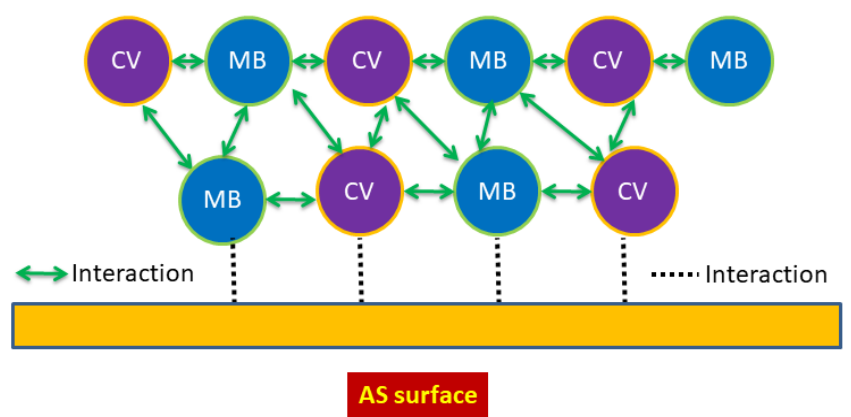

Figure 13. Proposed mechanism of adsorption of $\mathrm{MB}+\mathrm{CV}$ onto $\mathrm{AS}$ (AS dose $=8 \mathrm{~g} \mathrm{~L}^{-1}, t=15 \mathrm{~min}, T=22 \pm 1$

$\left.{ }^{\circ} \mathrm{C}\right)$.

\subsubsection{Mixture of CV with CR.}

The adsorption of $\mathrm{CV}$ and $\mathrm{CR}$ from $\mathrm{CV}+\mathrm{CR}$ on $\mathrm{AS}$ was studied, and the results are summarized in Figure 14. In analyzing these results, two different areas can be noted: the first is between $0 \%$ and $40 \% \mathrm{CV}$, corresponding to decreased quantities of adsorbed CR and CV this suggests that there is competition between the two dyes on available active sites $[40,78]$. The second begins when the CV becomes the majority (from 40 to $100 \%$ ). In this stage, we see an improvement in the amount of $\mathrm{CR}$ adsorbed may be justified by a synergy between already adsorbed CV molecules and CR molecules [10,76]. These will be themselves adsorbed to $\mathrm{CV}$ molecules due to attraction caused by differential loads between the CV molecules and the CR (Figure 15) [1]. 


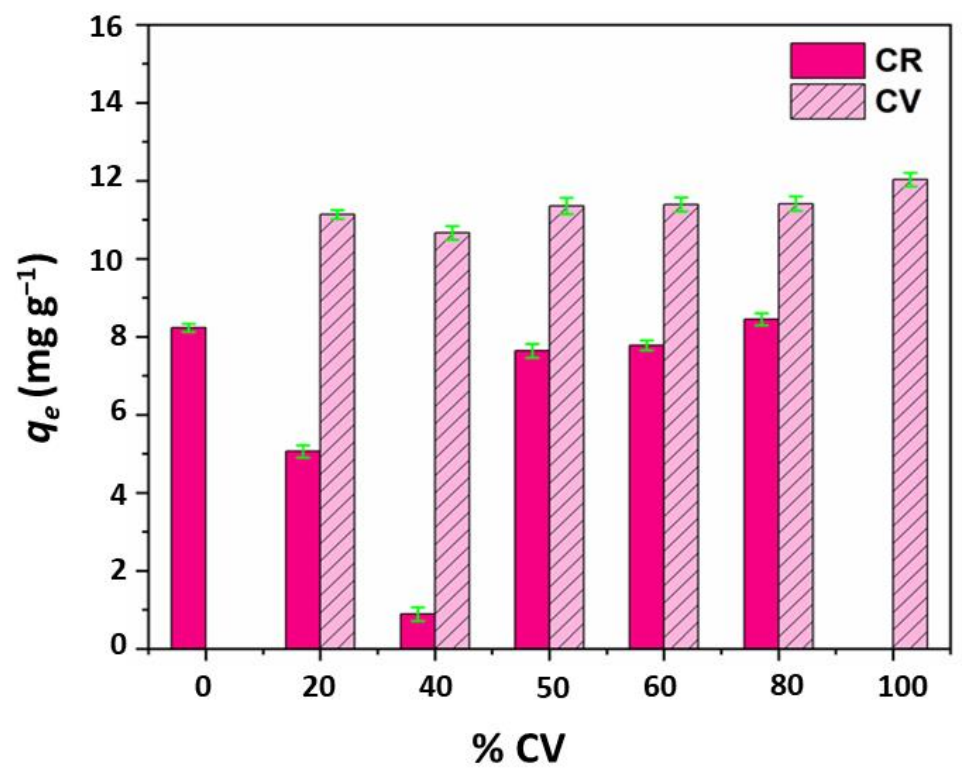

Figure 14. Adsorption of $\mathrm{CV}$ and $\mathrm{CR}$ a binary mixture of $\mathrm{CV}+\mathrm{CR}$ using $\mathrm{AS}$ AS dose $=8 \mathrm{~g} \mathrm{~L}{ }^{-1}, t=15 \mathrm{~min}, \mathrm{~T}=$ $\left.22 \pm 1^{\circ} \mathrm{C}\right)$.

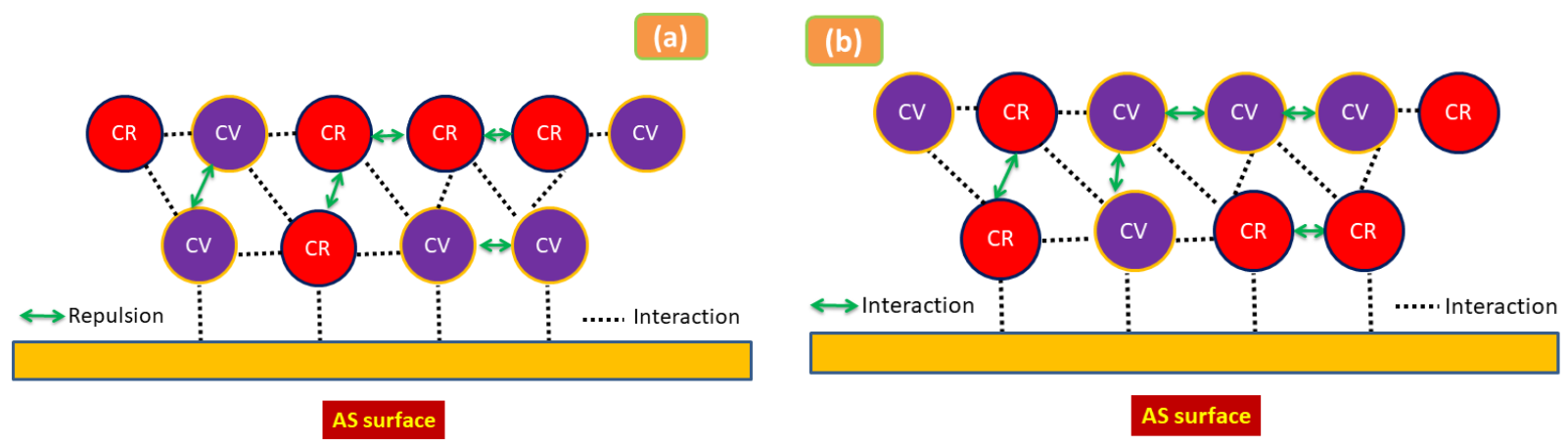

Figure 15. Proposed mechanism of adsorption of CV+CR onto AS: (a) CR majority; (b) CR minority.

\section{Conclusions}

The adsorption of methylene blue, crystal violet, and Congo red from an aqueous solution onto an almond shell has been studied. The experimental study showed that AS could remove $\mathrm{MB}, \mathrm{CV}$, and $\mathrm{CR}$ from an aqueous solution well and rapidly (10 minutes) and that treating it with some chemical materials can raise its efficiency. The pseudo-second-order kinetic and Langmuir isotherm models are fitted to reveal the adsorption of $\mathrm{MB}, \mathrm{CV}$, and $\mathrm{CR}$ in a single system with a capacity maximum was $52.35 \mathrm{mg} \mathrm{g}^{-1}, 44.78 \mathrm{mg} \mathrm{g}^{-1}$, and $26.92 \mathrm{mg} \mathrm{g}^{-}$ 1 , respectively. The adsorption of $\mathrm{MB}, \mathrm{CV}$, and CR on AS was spontaneous $\left(\Delta G^{\circ}<0\right)$ and exothermic $\left(\triangle S^{\circ}<0\right)$. Adsorption $\mathrm{MB}, \mathrm{CV}$, and $\mathrm{CR}$ from $\mathrm{CR}+\mathrm{MB}$ and $\mathrm{CR}+\mathrm{CV}$ were synergetic. The adsorption capacity of $\mathrm{CR}$ increased with the increasing volume of $\mathrm{MB}$ and $\mathrm{CV}$ in the mixture, while the adsorption $\mathrm{MB}$ and $\mathrm{CV}$ from $\mathrm{MB}+\mathrm{CV}$ were competitive. These results demonstrated that the almond shell is a promising adsorbent for the removal of dyes from wastewaters.

\section{Funding}

This research received no external funding. 


\section{Acknowledgments}

This work is supported by the Laboratory of Applied Chemistry and Environment, Ibn Zohr University, Agadir 80000, Morocco.

\section{Conflicts of Interest}

The authors declare no conflict of interest

\section{References}

1. Padhi, D.K.; Parida, K.M.; Singh, S.K. Mechanistic Aspects of Enhanced Congo Red Adsorption over Graphene Oxide in Presence of Methylene Blue. J. Environ. Chem. Eng. 2016, 4, 3498-3511, https://doi.org/10.1016/j.jece.2016.07.011.

2. Salleh, M. A.M.; Mahmoud, D.K.; Karim, W.A.W.A.; Idris, A. Cationic and Anionic Dye Adsorption by Agricultural Solid Wastes: A Comprehensive Review. Desalination. Elsevier October 3, 2011, 1-13, https://doi.org/10.1016/j.desal.2011.07.019.

3. Özdemir, A.; Keskin, C.S. Removal of a Binary Dye Mixture of Congo Red and Malachite Green from Aqueous Solutions Using a Bentonite Adsorbent. Clays Clay Miner. 2009, 57, 695-705, https://doi.org/10.1346/CCMN.2009.0570603.

4. Hamad, M.T. M.H.; Saied, M.S.S. Kinetic Studies of Congo Red Dye Adsorption by Immobilized Aspergillus Niger on Alginate. Appl. Water Sci. 2021, 11, 35, https://doi.org/10.1007/s13201-021-01362-z.

5. El Messaoudi, N.; El Khomri, M.; Dbik, A.; Bentahar, S.; Lacherai, A.; Bakiz, B. Biosorption of Congo Red in a Fixed-Bed Column from Aqueous Solution Using Jujube Shell: Experimental and Mathematical Modeling. J. Environ. Chem. Eng. 2016, 4, 3848-3855, https://doi.org/10.1016/j.jece.2016.08.027.

6. Nguyen, N.T.; Nguyen, N.T.; Nguyen, V.A. In Situ Synthesis and Characterization of ZnO/Chitosan Nanocomposite as an Adsorbent for Removal of Congo Red from Aqueous Solution. Adv. Polym. Technol. 2020, 2020, https://doi.org/10.1155/2020/3892694.

7. Chandane, V.; Singh, V.K. Adsorption of Safranin Dye from Aqueous Solutions Using a Low-Cost AgroWaste Material Soybean Hull. Desalin. Water Treat. 2016, 57, 4122-4134, https://doi.org/10.1080/19443994.2014.991758.

8. Sadaf, S.; Bhatti, H.N. Response Surface Methodology Approach for Optimization of Adsorption Process for the Removal of Indosol Yellow BG Dye from Aqueous Solution by Agricultural Waste. Desalin. Water Treat. 2016, 57, 11773-11781, https://doi.org/10.1080/19443994.2015.1048308.

9. Akpomie, K.G.; Conradie, J. Banana Peel as a Biosorbent for the Decontamination of Water Pollutants. A Review. Environmental Chemistry Letters. Springer July 1, 2020, 1085-1112, https://doi.org/10.1007/s10311-020-00995-X.

10. Bentahar, S.; Dbik, A.; Khomri, M.E.; El Messaoudi, N.; Lacherai, A. Adsorption of Methylene Blue, Crystal Violet and Congo Red from Binary and Ternary Systems with Natural Clay: Kinetic, Isotherm, and Thermodynamic. J. Environ. Chem. Eng. 2017, 5, 5921-5932, https://doi.org/10.1016/j.jece.2017.11.003.

11. Bhatnagar, A.; Sillanpää, M.; Witek-Krowiak, A. Agricultural Waste Peels as Versatile Biomass for Water Purification - A Review. Chemical Engineering Journal. Elsevier June 5, 2015, 244-271, https://doi.org/10.1016/j.cej.2015.01.135.

12. Ali, I.; Asim, M.; Khan, T.A. Low Cost Adsorbents for the Removal of Organic Pollutants from Wastewater. Journal of Environmental Management. Academic Press December 30, 2012, 170-183, https://doi.org/10.1016/j.jenvman.2012.08.028.

13. Bayram, T.; Bucak, S.; Ozturk, D. BR13 Dye Removal Using Sodium Dodecyl Sulfate Modified Montmorillonite: Equilibrium, Thermodynamic, Kinetic and Reusability Studies. Chem. Eng. Process. Process Intensif. 2020, 158, 108186, https://doi.org/10.1016/j.cep.2020.108186.

14. Wang, Q.; Lei, L.; Wang, F.; Chen, C.; Kang, X.; Wang, C.; Zhao, J.; Yang, Q.; Chen, Z. Preparation of Egg White@zeolitic Imidazolate Framework-8@polyacrylic Acid Aerogel and Its Adsorption Properties for Organic Dyes. J. Solid State Chem. 2020, 292, 121656, https://doi.org/10.1016/j.jssc.2020.121656.

15. El Messaoudi, N.; El Khomri, M.; Bentahar, S.; Dbik, A.; Lacherai, A.; Bakiz, B. Evaluation of Performance of Chemically Treated Date Stones: Application for the Removal of Cationic Dyes from Aqueous Solutions. J. Taiwan Inst. Chem. Eng. 2016, 67, 244-253, https://doi.org/10.1016/j.jtice.2016.07.024. 
16. Mehralian, M.; Goodarzvand Chegini, Z.; Khashij, M. Activated Carbon Prepared from Pistachio Waste for Dye Adsorption: Experimental and CCD-Based Design. Pigment Resin Technol. 2019, 49, 136-144, https://doi.org/10.1108/PRT-06-2019-0052.

17. Lakshmipathy, R.; Sarada, N.C. Adsorptive Removal of Basic Cationic Dyes from Aqueous Solution by Chemically Protonated Watermelon (Citrullus Lanatus) Rind Biomass. Desalin. Water Treat. 2014, 52, 61756184, https://doi.org/10.1080/19443994.2013.812526.

18. Lafi, R.; Hamdi, N.; Hafiane, A. Study of the Performance of Esparto Grass Fibers as Adsorbent of Dyes from Aqueous Solutions. Desalin. Water Treat. 2015, 56, 722-735, https://doi.org/10.1080/19443994.2014.950993.

19. Ashrafi, S.D.; Kamani, H.; Jaafari, J.; Mahvi, A.H. Experimental Design and Response Surface Modeling for Optimization of Fluoroquinolone Removal from Aqueous Solution by NaOH-Modified Rice Husk. Desalin. Water Treat. 2016, 57, 16456-16465, https://doi.org/10.1080/19443994.2015.1080188.

20. El Messaoudi, N.; El Khomri, M.; Chlif, N.; Chegini, Z.G.; Dbik, A.; Bentahar, S.; Lacherai, A. Desorption of Congo Red from Dye-Loaded Phoenix Dactylifera Date Stones and Ziziphus Lotus Jujube Shells. Groundw. Sustain. Dev. 2021, 12, 100552, https://doi.org/10.1016/j.gsd.2021.100552.

21. Ghorbani, F.; Kamari, S.; Zamani, S.; Akbari, S.; Salehi, M. Optimization and Modeling of Aqueous Cr(VI) Adsorption onto Activated Carbon Prepared from Sugar Beet Bagasse Agricultural Waste by Application of Response Surface Methodology. Surfaces and Interfaces 2020, 18, 100444, https://doi.org/10.1016/j.surfin.2020.100444.

22. Abbas, A.F.; Ahmed, M.J. Mesoporous Activated Carbon from Date Stones (Phoenix Dactylifera L.) by OneStep Microwave Assisted K2CO3 Pyrolysis. J. Water Process Eng. 2016, 9, 201-207, https://doi.org/10.1016/j.jwpe.2016.01.004.

23. El Messaoudi, N.; Dbik, A.; El Khomri, M.; Sabour, A.; Bentahar, S.; Lacherai, A. Date Stones of Phoenix Dactylifera and Jujube Shells of Ziziphus Lotus as Potential Biosorbents for Anionic Dye Removal. Int. J. Phytoremediation 2017, 19, 1047-1052, https://doi.org/10.1080/15226514.2017.1319331.

24. El Messaoudi, N.; El Khomri, M.; Dbik, A.; Bentahar, S.; Lacherai, A. Selective and Competitive Removal of Dyes from Binary and Ternary Systems in Aqueous Solutions by Pretreated Jujube Shell (Zizyphus Lotus). J. Dispers. Sci. Technol. 2017, 38, 1168-1174, https://doi.org/10.1080/01932691.2016.1228070.

25. da Silva, A.M.B.; Serrão, N.O.; de Gusmão Celestino, G.; Takeno, M.L.; Antunes, N.T.B.; Iglauer, S.; Manzato, L.; de Freitas, F.A.; Maia, P.J.S. Removal of Rhodamine 6G from Synthetic Effluents Using Clitoria Fairchildiana Pods as Low-Cost Biosorbent. Environ. Sci. Pollut. Res. 2020, 27, 2868-2880, https://doi.org/10.1007/s11356-019-07114-6.

26. Rizzi, V.; D’Agostino, F.; Fini, P.; Semeraro, P.; Cosma, P. An Interesting Environmental Friendly Cleanup: The Excellent Potential of Olive Pomace for Disperse Blue Adsorption/Desorption from Wastewater. Dye. Pigment. 2017, 140, 480-490, https://doi.org/10.1016/j.dyepig.2017.01.069.

27. Kong, L.; Gong, L.; Wang, J. Removal of Methylene Blue from Wastewater Using Fallen Leaves as an Adsorbent. Desalin. Water Treat. 2015, 53, 2489-2500, https://doi.org/10.1080/19443994.2013.863738.

28. Uddin, M.K.; Nasar, A. Walnut Shell Powder as a Low-Cost Adsorbent for Methylene Blue Dye: Isotherm, Kinetics, Thermodynamic, Desorption and Response Surface Methodology Examinations. Sci. Rep. 2020, 10, 1-13, https://doi.org/10.1038/s41598-020-64745-3.

29. Al-Zoubi, H.; Zubair, M.; Manzar, M.S.; Manda, A.A.; Blaisi, N.I.; Qureshi, A.; Matani, A. Comparative Adsorption of Anionic Dyes (Eriochrome Black T and Congo Red) onto Jojoba Residues: Isotherm, Kinetics and Thermodynamic Studies. Arab. J. Sci. Eng. 2020, 45, 7275-7287, https://doi.org/10.1007/s13369-02004418-5.

30. Kaur, R.; Kaur, H. Calotropis Procera an Effective Adsorbent for Removal of Congo Red Dye: Isotherm and Kinetics Modelling. Model. Earth Syst. Environ. 2017, 3, 1-13, https://doi.org/10.1007/s40808-017-0274-3.

31. Unugul, T.; Nigiz, F.U. Preparation and Characterization an Active Carbon Adsorbent from Waste Mandarin Peel and Determination of Adsorption Behavior on Removal of Synthetic Dye Solutions. Water, Air, and Soil Pollution. Springer Science and Business Media Deutschland GmbH November 1, 2020, 1-14, https://doi.org/10.1007/s11270-020-04903-5.

32. Mondal, N.K.; Kar, S. Potentiality of Banana Peel for Removal of Congo Red Dye from Aqueous Solution: Isotherm, Kinetics and Thermodynamics Studies. Appl. Water Sci. 2018, 8, 157 , https://doi.org/10.1007/s13201-018-0811-x.

33. Filho, A.C.D.; Mazzocato, A. C.; Dotto, G. L.; Thue, P. S.; Pavan, F. A. Eragrostis Plana Nees as a Novel Eco-Friendly Adsorbent for Removal of Crystal Violet from Aqueous Solutions. Environ. Sci. Pollut. Res. 
2017, 24, 19909-19919, https://doi.org/10.1007/s11356-017-9365-y.

34. Asgher, M.; Bhatti, H.N. Removal of Reactive Blue 19 and Reactive Blue 49 Textile Dyes by Citrus Waste Biomass from Aqueous Solution: Equilibrium and Kinetic Study. Can. J. Chem. Eng. 2012, 90, 412-419, https://doi.org/10.1002/cjce.20531.

35. Duran, C.; Ozdes, D.; Gundogdu, A.; Senturk, H.B. Kinetics and Isotherm Analysis of Basic Dyes Adsorption onto Almond Shell (Prunus Dulcis) as a Low Cost Adsorbent. J. Chem. Eng. Data 2011, 56, 2136-2147, https://doi.org/10.1021/je101204j.

36. Doulati Ardejani, F.; Badii, K.; Limaee, N.Y.; Shafaei, S.Z.; Mirhabibi, A.R. Adsorption of Direct Red 80 Dye from Aqueous Solution onto Almond Shells: Effect of PH, Initial Concentration and Shell Type. $J$. Hazard. Mater. 2008, 151, 730-737, https://doi.org/10.1016/j.jhazmat.2007.06.048.

37. Ben Arfi, R.; Karoui, S.; Mougin, K.; Ghorbal, A. Adsorptive Removal of Cationic and Anionic Dyes from Aqueous Solution by Utilizing Almond Shell as Bioadsorbent. Euro-Mediterranean J. Environ. Integr. 2017, 2, 1-13, https://doi.org/10.1007/s41207-017-0032-y.

38. Maaloul, N.; Oulego, P.; Rendueles, M.; Ghorbal, A.; Díaz, M. Novel Biosorbents from Almond Shells: Characterization and Adsorption Properties Modeling for $\mathrm{Cu}(\mathrm{II})$ Ions from Aqueous Solutions. J. Environ. Chem. Eng. 2017, 5, 2944-2954, https://doi.org/10.1016/j.jece.2017.05.037.

39. Fiol, N.; Villaescusa, I. Determination of Sorbent Point Zero Charge: Usefulness in Sorption Studies. Environ. Chem. Lett. 2009, 7, 79-84, https://doi.org/10.1007/s10311-008-0139-0.

40. Gonçalves, J.O.; Santos, J.P.; Rios, E.C.; Crispim, M.M.; Dotto, G.L.; Pinto, L.A.A. Development of Chitosan Based Hybrid Hydrogels for Dyes Removal from Aqueous Binary System. J. Mol. Liq. 2017, 225, 265-270, https://doi.org/10.1016/j.molliq.2016.11.067.

41. Mahmoodi, N.M.; Salehi, R.; Arami, M.; Bahrami, H. Dye Removal from Colored Textile Wastewater Using Chitosan in Binary Systems. Desalination 2011, 267, 64-72, https://doi.org/10.1016/j.desal.2010.09.007.

42. El Khomri, M.; El Messaoudi, N.; Dbik, A.; Bentahar, S.; Lacherai, A. Efficient Adsorbent Derived from Argania Spinosa for the Adsorption of Cationic Dye: Kinetics, Mechanism, Isotherm and Thermodynamic Study. Surfaces and Interfaces 2020, 20, 100601, https://doi.org/10.1016/j.surfin.2020.100601.

43. Khan, M.A.; Al Othman, Z.A.; Kumar, M.; Ola, M.S.; Siddique, M.R. Biosorption Potential Assessment of Modified Pistachio Shell Waste for Methylene Blue: Thermodynamics and Kinetics Study. Desalin. Water Treat. 2015, 56, 146-160, https://doi.org/10.1080/19443994.2014.934728.

44. Salomón, Y.L.d.O.; Georgin, J.; Franco, D.S.P.; Netto, M.S.; Grassi, P.; Piccilli, D.G.A.; Oliveira, M.L.S.; Dotto, G.L. Powdered Biosorbent from Pecan Pericarp (Carya Illinoensis) as an Efficient Material to Uptake Methyl Violet 2B from Effluents in Batch and Column Operations. Adv. Powder Technol. 2020, 31, 28432852, https://doi.org/10.1016/j.apt.2020.05.004.

45. Shakoor, S.; Nasar, A. Utilization of Cucumis Sativus Peel as an Eco-Friendly Biosorbent for the Confiscation of Crystal Violet Dye from Artificially Contaminated Wastewater . Anal. Chem. Lett. 2019, 9, 1-19, https://doi.org/10.1080/22297928.2019.1588162.

46. Siengchum, T.; Isenberg, M.; Chuang, S.S.C. Fast Pyrolysis of Coconut Biomass - An FTIR Study. Fuel 2013, 105, 559-565, https://doi.org/10.1016/j.fuel.2012.09.039.

47. Loulidi, I.; Boukhlifi, F.; Ouchabi, M.; Amar, A.; Jabri, M.; Kali, A.; Chraibi, S.; Hadey, C.; Aziz, F. Adsorption of Crystal Violet onto an Agricultural Waste Residue: Kinetics, Isotherm, Thermodynamics, and Mechanism of Adsorption. Sci. World J. 2020, 2020, https://doi.org/10.1155/2020/5873521.

48. Jawad, A.H.; Abdulhameed, A.S. Statistical Modeling of Methylene Blue Dye Adsorption by High Surface Area Mesoporous Activated Carbon from Bamboo Chip Using KOH-Assisted Thermal Activation. Energy, Ecol. Environ. 2020, 5, 456-469, https://doi.org/10.1007/s40974-020-00177-z.

49. Surip, S.N.; Abdulhameed, A.S.; Garba, Z.N.; Syed-Hassan, S.S.A.; Ismail, K.; Jawad, A.H. H2SO4-Treated Malaysian Low Rank Coal for Methylene Blue Dye Decolourization and Cod Reduction: Optimization of Adsorption and Mechanism Study. Surfaces and Interfaces 2020, 21, 100641, https://doi.org/10.1016/j.surfin.2020.100641.

50. Feng, N.C.; Guo, X.Y. Characterization of Adsorptive Capacity and Mechanisms on Adsorption of Copper, Lead and Zinc by Modified Orange Peel. Trans. Nonferrous Met. Soc. China (English Ed. 2012, 22, 12241231, https://doi.org/10.1016/S1003-6326(11)61309-5.

51. Singh, J.; Ali, A.; Jaswal, V.S.; Prakash, V. Desalination of $\mathrm{Cd} 2+$ and $\mathrm{Pb} 2+$ from Paint Industrial Wastewater by Aspergillus Niger Decomposed Citrus Limetta Peel Powder. Int. J. Environ. Sci. Technol. 2015, 12, $2523-$ 2532, https://doi.org/10.1007/s13762-014-0620-1.

52. Vargas, V.H.; Paveglio, R.R.; Pauletto, P.deS.; Salau, N.P.G.; Dotto, L.G. Sisal Fiber as an Alternative and 
Cost-Effective Adsorbent for the Removal of Methylene Blue and Reactive Black 5 Dyes from Aqueous Solutions. Chem. Eng. Commun. 2020, 207, 523-536, https://doi.org/10.1080/00986445.2019.1605362.

53. Hoang, L.P.; Van, H.T.; Hang Nguyen, T.T.; Nguyen, V.Q.; Thang, P.Q. Coconut Shell Activated Carbon/CoFe2O4 Composite for the Removal of Rhodamine B from Aqueous Solution. J. Chem. 2020, 2020, https://doi.org/10.1155/2020/9187960.

54. Rouhi, M.; Lakouraj, M.M.; Tashakkorian, H.; Hasantabar, V. Novel Carbon Based Bioactive Nanocomposites of Aniline/Indole Copolymer for Removal of Cationic Dyes from Aqueous Solution: Kinetics and Isotherms. New J. Chem. 2019, 43, 2400-2410, https://doi.org/10.1039/c8nj02924e.

55. Aljeboree, A.M.; Alshirifi, A.N.; Alkaim, A.F. Kinetics and Equilibrium Study for the Adsorption of Textile Dyes on Coconut Shell Activated Carbon. Arab. J. Chem. 2017, 10, S3381-S3393, https://doi.org/10.1016/j.arabjc.2014.01.020.

56. Ahmad, R.; Kumar, R. Adsorptive Removal of Congo Red Dye from Aqueous Solution Using Bael Shell Carbon. Appl. Surf. Sci. 2010, 257, 1628-1633, https://doi.org/10.1016/j.apsusc.2010.08.111.

57. Lima, E.C.; Sher, F.; Guleria, A.; Saeb, M.R.; Anastopoulos, I.; Tran, H.N.; Hosseini-Bandegharaei, A. Is One Performing the Treatment Data of Adsorption Kinetics Correctly? J. Environ. Chem. Eng. 2020, 9, 104813, https://doi.org/10.1016/j.jece.2020.104813.

58. Nyankson, E.; Adjasoo, J.; Efavi, J. K.; Yaya, A.; Manu, G.; Kingsford, A.; Abrokwah, R. Y. Synthesis and Kinetic Adsorption Characteristics of Zeolite/CeO2 Nanocomposite. Sci. African 2020, 7, e00257, https://doi.org/10.1016/j.sciaf.2019.e00257.

59. Tahir, N.; Bhatti, H.N.; Iqbal, M.; Noreen, S. Biopolymers Composites with Peanut Hull Waste Biomass and Application for Crystal Violet Adsorption. Int. J. Biol. Macromol. 2017, 94, 210-220, https://doi.org/10.1016/j.ijbiomac.2016.10.013.

60. Tiwari, D.P.; Singh, S.K.; Sharma, N. Sorption of Methylene Blue on Treated Agricultural Adsorbents: Equilibrium and Kinetic Studies. Appl. Water Sci. 2015, 5, 81-88, https://doi.org/10.1007/s13201-014-01710 .

61. Bentahar, S.; Dbik, A.; Khomri, M.E.; El Messaoudi, N.; Lacherai, A. Removal of a Cationic Dye from Aqueous Solution by Natural Clay. Groundw. Sustain. Dev. 2018, 6, 255-262, https://doi.org/10.1016/j.gsd.2018.02.002.

62. Jerold, M.; Vasantharaj, K.; Joseph, D.; Sivasubramanian, V. Fabrication of Hybrid Biosorbent Nanoscale Zero-Valent Iron-Sargassum Swartzii Biocomposite for the Removal of Crystal Violet from Aqueous Solution. Int. J. Phytoremediation 2017, 19, 214-224, https://doi.org/10.1080/15226514.2016.1207607.

63. Córdova, B.M.; Santa Cruz, J.P.; Ocampo, T.V.M.; Huamani-Palomino, R.G.; Baena-Moncada, A.M. Simultaneous Adsorption of a Ternary Mixture of Brilliant Green, Rhodamine B and Methyl Orange as Artificial Wastewater onto Biochar from Cocoa Pod Husk Waste. Quantification of Dyes Using the Derivative Spectrophotometry Method. New J. Chem. 2020, 44, 8303-8316, https://doi.org/10.1039/d0nj00916d.

64. Liang, T.; Wang, F.; Liang, L.; Liu, M.; Sun, J. Magnetically Separable Nitrogen-Doped Mesoporous Carbon with High Adsorption Capacity. J. Mater. Sci. 2016, 51, 3868-3879, https://doi.org/10.1007/s10853-0159706-5.

65. Zhou, L.; Jin, J.; Liu, Z.; Liang, X.; Shang, C. Adsorption of Acid Dyes from Aqueous Solutions by the Ethylenediamine-Modified Magnetic Chitosan Nanoparticles. J. Hazard. Mater. 2011, 185, 1045-1052, https://doi.org/10.1016/j.jhazmat.2010.10.012.

66. Lima, E.C.; Hosseini-Bandegharaei, A.; Moreno-Piraján, J.C.; Anastopoulos, I. A Critical Review of the Estimation of the Thermodynamic Parameters on Adsorption Equilibria. Wrong Use of Equilibrium Constant in the Van't Hoof Equation for Calculation of Thermodynamic Parameters of Adsorption. J. Mol. Liq. 2019, 273, 425-434, https://doi.org/10.1016/j.molliq.2018.10.048.

67. Saber-Samandari, S.; Saber-Samandari, S.; Nezafati, N.; Yahya, K. Efficient Removal of Lead (II) Ions and Methylene Blue from Aqueous Solution Using Chitosan/Fe-Hydroxyapatite Nanocomposite Beads. J. Environ. Manage. 2014, 146, 481-490, https://doi.org/10.1016/j.jenvman.2014.08.010.

68. Hao, X.; Song, X.; Li, K.; Wang, C.; Li, K.; Li, Y.; Sun, X.; Ning, P. Theoretical Study on NO: X Adsorption Properties over the $\alpha-\mathrm{MnO} 2(110)$ Surface. RSC Adv. 2020, 10, 9539-9548, https://doi.org/10.1039/c9ra09455e.

69. Dbik, A.; Bentahar, S.; El Khomri, M.; El Messaoudi, N.; Lacherai, A. Adsorption of Congo Red Dye from Aqueous Solutions Using Tunics of the Corm of the Saffron. In Materials Today: Proceedings; Elsevier Ltd, 2020; 22, 134-139, https://doi.org/10.1016/j.matpr.2019.08.148. 
70. Sakkayawong, N.; Thiravetyan, P.; Nakbanpote, W. Adsorption Mechanism of Synthetic Reactive Dye Wastewater by Chitosan. J. Colloid Interface Sci. 2005, 286, 36-42, https://doi.org/10.1016/j.jcis.2005.01.020.

71. Dinh, V.P.; Huynh, T.D.T.; Le, H.M.; Nguyen, V.D.; Dao, V.A.; Hung, N.Q.; Tuyen, L.A.; Lee, S.; Yi, J.; Nguyen, T.D.; Tan, L.V. Insight into the Adsorption Mechanisms of Methylene Blue and Chromium(III) from Aqueous Solution onto Pomelo Fruit Peel. RSC Adv. 2019, 9, 25847-25860, https://doi.org/10.1039/c9ra04296b.

72. Jawad, A.H.; Abdulhameed, A.S.; Mastuli, M.S. Acid-Factionalized Biomass Material for Methylene Blue Dye Removal: A Comprehensive Adsorption and Mechanism Study. J. Taibah Univ. Sci. 2020, 14, 305-313, https://doi.org/10.1080/16583655.2020.1736767.

73. Bounaas, M.; Bouguettoucha, A.; Chebli, D.; Gatica, J.M.; Vidal, H. Role of the Wild Carob as Biosorbent and as Precursor of a New High-Surface-Area Activated Carbon for the Adsorption of Methylene Blue. Arab. J. Sci. Eng. 2021, 46, 325-341, https://doi.org/10.1007/s13369-020-04739-5.

74. El Messaoudi, N.; El Khomri, M.; Goodarzvand Chegini, Z.; Chlif, N.; Dbik, A.; Bentahar, S.; Iqbal, M.; Jada, A.; Lacherai, A. Desorption Study and Reusability of Raw and $\mathrm{H}_{2} \mathrm{SO}_{4}$ Modified Jujube Shells (Zizyphus Lotus ) for the Methylene Blue Adsorption. Int. J. Environ. Anal. Chem. 2021, 1-17, https://doi.org/10.1080/03067319.2021.1912338.

75. Yahyaei, B.; Azizian, S. Rapid Adsorption of Binary Dye Pollutants onto the Nanostructred Mesoporous Alumina. J. Mol. Liq. 2014, 199, 88-95, https://doi.org/10.1016/j.molliq.2014.08.023.

76. Sharma, K.; Dalai, A. K.; Vyas, R. K. Removal of Synthetic Dyes from Multicomponent Industrial Wastewaters. Rev. Chem. Eng. 2017, 34, 107-134, https://doi.org/10.1515/revce-2016-0042.

77. Turabik, M. Adsorption of Basic Dyes from Single and Binary Component Systems onto Bentonite: Simultaneous Analysis of Basic Red 46 and Basic Yellow 28 by First Order Derivative Spectrophotometric Analysis Method. J. Hazard. Mater. 2008, 158, 52-64, https://doi.org/10.1016/j.jhazmat.2008.01.033.

78. Mahmoodi, N.M.; Hayati, B.; Arami, M.; Lan, C. Adsorption of Textile Dyes on Pine Cone from Colored Wastewater: Kinetic, Equilibrium and Thermodynamic Studies. Desalination 2011, 268, 117-125, https://doi.org/10.1016/j.desal.2010.10.007. 